2002s-77

\title{
Working Hours of the World Unite? \\ New International Evidence on \\ Worktime, 1870-1900
}

Michael Huberman

\begin{tabular}{c}
\hline Série Scientifique \\
Scientific Series
\end{tabular}

Montréal

Septembre 2002

(C) 2002 Michael Huberman. Tous droits réservés. All rights reserved. Reproduction partielle permise avec citation du document source, incluant la notice (C).

Short sections may be quoted without explicit permission, if full credit, including $@$ notice, is given to the source.
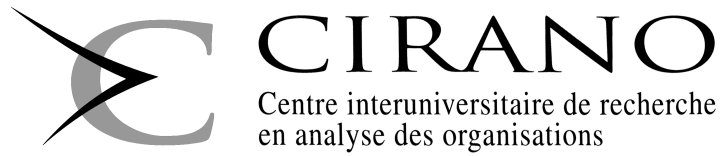

Centre interuniversitaire de recherche en analyse des organisations 


\section{CIRANO}

Le CIRANO est un organisme sans but lucratif constitué en vertu de la Loi des compagnies du Québec. Le financement de son infrastructure et de ses activités de recherche provient des cotisations de ses organisationsmembres, d'une subvention d'infrastructure du ministère de la Recherche, de la Science et de la Technologie, de même que des subventions et mandats obtenus par ses équipes de recherche.

CIRANO is a private non-profit organization incorporated under the Québec Companies Act. Its infrastructure and research activities are funded through fees paid by member organizations, an infrastructure grant from the Ministère de la Recherche, de la Science et de la Technologie, and grants and research mandates obtained by its research teams.

\section{Les organisations-partenaires / The Partner Organizations}

-École des Hautes Études Commerciales

-École Polytechnique de Montréal

-Université Concordia

-Université de Montréal

-Université du Québec à Montréal

-Université Laval

-Université McGill

-Ministère des Finances du Québec

-MRST

-Alcan inc.

- AXA Canada

-Banque du Canada

-Banque Laurentienne du Canada

- Banque Nationale du Canada

- Banque Royale du Canada

-Bell Canada

-Bombardier

-Bourse de Montréal

-Développement des ressources humaines Canada (DRHC)

-Fédération des caisses Desjardins du Québec

-Hydro-Québec

-Industrie Canada

-Pratt \& Whitney Canada Inc.

-Raymond Chabot Grant Thornton

-Ville de Montréal

Les cahiers de la série scientifique (CS) visent à rendre accessibles des résultats de recherche effectuée au CIRANO afin de susciter échanges et commentaires. Ces cahiers sont écrits dans le style des publications scientifiques. Les idées et les opinions émises sont sous l'unique responsabilité des auteurs et ne représentent pas nécessairement les positions du CIRANO ou de ses partenaires.

This paper presents research carried out at CIRANO and aims at encouraging discussion and comment.

The observations and viewpoints expressed are the sole responsibility of the authors. They do not necessarily represent positions of CIRANO or its partners. 


\title{
Working Hours of the World Unite? New International Evidence on Worktime, 1870-1900*
}

\author{
Michael Huberman $\dagger$
}

\begin{abstract}
Résumé / Abstract
Le plus connu des corpus de données sur le temps de travail au cours du long dix-neuvième siècle, réuni par Angus Maddison, est sérieusement erroné, car il présume que tous les pays avaient les mêmes heures de travail que celles des Britanniques. Cet article présente de nouvelles mesures du temps de travail pour l'Europe, l'Amérique du Nord et l'Australie, entre 1870 et 1900. À l'exception de la Grande-Bretagne et de l'Australie, les heures de travail étaient très longues, avec des rythmes de décroissance différents selon les pays. La longueur de la semaine de travail était inversement proportionnelle au niveau de revenu, mais avec une légère tendance convergente ou un rattrapage tel que la théorie le prévoyait. Les routines de travail et les lois régissant les heures de travail expliquent certaines différences, mais les particularités sectorielles vont dans le sens opposé. Au sein des industries concurrentielles, comme les textiles, il y avait un nivellement par le bas. Comme les longues heures de travail constituaient un avantage compétitif, même le travailleur du textile au Lancashire a dû ajuster sa montre à l'heure italienne.

Assembled by Angus Maddison, the most widely consulted data set on worktime in the long nineteenth century is seriously flawed, because it assumes all countries had British work hours. This paper constructs new measures of worktime in Europe, North America and Australia between 1870 and 1900. With the exception of Great Britain and Australia, work hours were very long. Trends in worktime varied across countries. The length of the workweek was inversely related to the level of income, but there was only a modest tendency toward convergence or catch-up as theory anticipates. National work routines and laws restricting working hours explain some of the divergence, but sectoral effects operated in the other direction. Competinggoods industries, like textiles, saw a race to the bottom. Because long hours were a source of competitive advantage, even the Lancashire textile worker set his watch to Italian time.
\end{abstract}

Mots clés : Mondialisation, commerce international, temps de travail, intégration économique.

Keywords: Globalization, international trade, work hours, economic integration.

\footnotetext{
* Preliminary. Please do not cite without permission.

† Université de Montréal, CIRANO, CIREQ. Contact address: michael.huberman@umontreal.ca.
} 


\section{Introduction}

Albert Rees, in his classic labor economics textbook, asserted that the decision to labor 72 hour per week "in the early days of the industrial revolution" was neither implausible nor impractical. At very low real wages, "with habituation and a less intense pace of work, output could continue to rise with increases in the workweek well beyond any number of hours we could now regard as reasonable." 1 But as wages and incomes rose, hours fell - a pattern, according to the ubiquitous belief among economists, that holds across space as well. "[T]here is strong empirical evidence that the optimal length of the workweek is negatively correlated with a nation's level of income; that is, high-income countries have a shorter workweek than many lowincome countries.",2

The late nineteenth century is a puzzle for the standard view. Owing to increased international mobility of labor and the expansion of trade, real wages rose almost everywhere in the period. Work hours should have declined globally and converged - a type of race to the top - because developing countries grew more rapidly and caught up to richer ones. Extending this line reasoning, Hans-Joachim Voth argued that at comparable levels of income less developed countries in the late nineteenth century ought to have worked fewer hours than richer countries because of the gradual substitution of human capital for labor time. ${ }^{3}$ But in the face of these forces, worktime measures for poorer and richer countries, across Old and New Worlds, hardly changed. For the UK, Robin Matthews, Charles Feinstein and J. C. Odling-Smee calculated 2,744 annual work hours in 1873, and 2,753 in 1913; for the US, Jeremy Atack, Fred Batemen and Robert Margo found that the working day in 1900 was not much shorter than in 1880. ${ }^{4}$ Across countries, higher income economies did not always work less than relatively poorer ones. In 1900 annual work hours in France stood at 3,000, about 300 more than in Italy, whose income per head was more than fifty percent less. ${ }^{5}$

There are two sorts of explanations for these trends. The first is that international comparisons of worktime confront serious data problems. Annual measures of worktime are

\footnotetext{
${ }^{1}$ According to Rees (Economics of Work, p. 26), much of the empirical evidence usually cited to show the adverse effect of long hours on output comes from abnormally long hours in wartime. "These hours were worked by workers who were either accustomed to shorter hours or were new wartime recruits. They worked long hours at high money wages at a time when there was a severe shortage of goods." In these circumstances, 54 hours may have been the maximum length of the workweek. But "this evidence is not inconsistent with an output maximizing figure of 60 or even 72 hours a week a century earlier." See also Phelps Brown and Browne, "Hours of Work."

${ }^{2}$ Brown, "Labor Standards," p. 91. For a similar statement, see Voth, Time and Work, p. 255. “...GDP per capita alone explains a high proportion of changes in time allocation."

${ }^{3}$ Ibid., pp. 258-68.

${ }^{4}$ Matthews, Feinstein, and Odling-Smee, British Growth, p. 566; Atack, Batemen, and Margo, "Productivity in Manufacturing," p. 16.

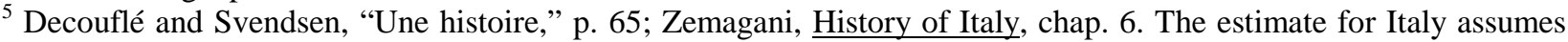
270 days of work per year and 10 hours per day.
} 
imprecise. Not only do standards of measurement vary across countries, but annual figures are composite estimates of approximations of the length of the workday and workweek, and the number of weeks worked per year. Errors in measurement are compounded because estimates of weekly hours are often based on a single sector of activity. The interplay of demand and supply provides the second type of explanation of the trend in hours. The long workday and year may have been the outcome of demand side pressure from employers to extend the time use of their capital investments. As for supply, workers may have been caught up in a second "industrious revolution." With increased exposure to foreign trade, households may have been willing to supply more labor time and reduce household production to acquire new foreign goods. Despite these forces, there may have been a timing problem in matching wage and hour changes, thereby forestalling the movement to new equilibria that better reflected rising levels of personal income. M. A. Bienefeld argued that since hours are more difficult to adjust than wages worktime changes are infrequent, but when they do occur, they are often large and concentrated in single years. ${ }^{6}$ Thus, hour cuts were postponed in many countries until after the First World War..

This paper provides an empirical investigation of some of these issues. Exploiting a new international data set of working hours in Europe, North America and Australia, I examine the length of the workweek and year and the dispersion of work hours across countries and sectors. With the exception of Great Britain and Australia, work hours were very long in the period. The trend in worktime is more difficult to discern. The length of the workweek was, as theory anticipates, inversely related to the level of income, but there were offsetting influences. In certain countries and regions, like France and northern Europe, worktime showed little change; in others like Germany and Switzerland, there was a marked downward trend. National work routines, cultural practices, and protective legislation may explain some of these divergences. There were also sectoral effects. Corresponding to the trends in the prices of competing and non-competing goods Jeffrey Williamson and Kevin O'Rourke found in their study of globalization, average hours were less likely to decline - and more likely to converge - in those sectors, like textiles, which faced strong international pressures. The British, despite their preeminent position in the industry, adjusted their clock to Italian work practices. In these sectors, working hours were subject to a race to the bottom. ${ }^{7}$ All told, national and international forces had often opposing effects on the length of the workday, and, as a result, across the New and Old World convergence of worktime was modest at best.

\footnotetext{
${ }^{6}$ Bienefeld, Working Hours.

${ }^{7}$ O'Rourke and Williamson, "Globalization."
} 


\section{Working time across countries: old and new estimates}

As a preliminary step in estimating employment and productivity for a group of OECD countries, Angus Maddison, in a series of articles and books, assembled an international data set on worktime that can be taken as the point of reference for more recent estimates. ${ }^{8}$ Table 1 reproduces the hours per week series for 1870, 1900, and 1913 Maddison used as the basis for his calculations. Because of data limitations, he assumed that all countries had the same work hours as Britain until 1913, even Canada and the US. Maddison went on to write:

Because of the uncertainty surrounding these [hours of work] rather arbitrary figures, we have assumed that the movement in working hours from 1870 to 1913 was the same in all our countries [Western Europe and North America]. This is probably a reasonable assumption. ${ }^{9}$

Columns 4 and 5 of the table give Maddison's estimates for the number of weeks worked based on evidence from the interwar years. Maddison did not explain how the modest variation between countries was arrived at. To calculate annual measures, Maddison multiplied weekly hours and number of weeks worked, and then made some deductions for time loss. He did not specify the breakdown of days not at work into its standard components, illness, unemployment or stoppages. The deductions were the same for all countries and amounted to 7.1 percent in 1870, 4.5 percent in 1900, and 2.5 percent in 1913. The last three columns in the table reproduces the estimated annual hours series for 1870, 1900 and 1913. As anticipated, given its method of construction, Maddison's series show conformity in worktime measures across countries.

Maddison's assumptions may have made little difference for his analysis of productivity growth (GDP per hour worked) over the long twentieth century from 1870 to 1998. But it is even more evident that his worktime measures before 1913 can be improved upon. In this paper, I draw on two unique sources that provide the building blocks for an international comparison of worktime during the early wave of globalization. The first source comprises the reports of the consular delegates to the British trade office beginning in the early 1870s. Even by this date, there was some unease expressed that shorter hours would make British industry uncompetitive, and to verify its concerns the Board of Trade had its representatives across the world collect data on working conditions and hours in order to isolate the sources of international competitiveness. ${ }^{10}$

\footnotetext{
${ }^{8}$ Maddison, Economic Growth, Phases of Development, "Growth and Slowdown”, Monitoring, World Economy.

${ }^{9}$ Maddison, Economic Growth, p. 225.

${ }^{10}$ UK PP 1870 LXVI, PP 1871 LXVIII, PP 1872 LXII. The consular reports were superseded by the Abstract of Foreign Labour Statistics and the Commission on Labour, Foreign Reports published occasionally before the First World War. PP 1899 XCII, PP 1901 LXXIII, PP 1906 CXIII, PP 1893-94 XXXIX.
} 
Table 2 summarizes worktime information from the reports for common day laborers. For Russia, the consular delegate observed:

... [T] he number of festivals on which work is prohibited in all factories is 19, but in most cases 27 or 28 festivals are kept as holidays during the year. Thus the average number of holidays, including Sunday is 80 or even 100 days, so only 250 or 260 days are spent at work.... In Poland the number of working days is further reduced to 230 on an average, because in Russia religious festivals are observed according to the Julian calendar, while in Poland they are celebrated twice over, according to both the Gregorian and Julian calendars. Thus a Russian does at least 70 days less work during a year than a Frenchman in a similar position. ${ }^{11}$

For the rest of Europe and the New World festival or holy days were less frequent, as illustrated by the increase in workdays after 1870 in Belgium, France and Italy. Still there existed a large difference in workdays between north and south, the gap between Italy and the Netherlands was about three weeks, and the New World had fewer days off than the Old. Evidently, national work routines mattered into the late nineteenth century. The overall average was about 300 days, and excluding Sunday work, this translates into about 49 weeks of work per year.

The second source I have relied upon gives detailed information on work hours per week. The US Department of Labor (1900), under the supervision of Carroll Wright, collected data on weekly work hours for the period 1850 to 1899 for a group of industrializing and industrialized countries. ${ }^{12}$ The Department consulted over 700 sources on non-agricultural work hours, mainly published and unpublished government accounts. Covering a long time span, the report combines both manufacturing and non-manufacturing sectors, and, in this regard, is more reliable than series that rely on observations of a small sample of businesses, usually textile mills or mines, for shorter periods. The report distinguished as well between women's and men's work hours. Because of data limitations for the early years, I restrict myself to the period between 1870 and 1899. Table 3 gives the relevant descriptive statistics. The Department's survey is heavily weighted toward the United States, and, to a lesser extent, Great Britain. Each observation represents the average hours worked by one or a group of similar workers, such as male cotton spinners, in a specific firm. Where summer and winter hours were reported, I took the average of the two. Of the 5,000 or so European observations, about 55 percent are from Britain and 15 percent from Germany and France. The survey's breakdown by sector is roughly similar across countries (services account for between five to eight percent, and textile and manufacturing

\footnotetext{
${ }^{11}$ PP 1893-94 XXXIX, Part II, p. 864. The figure for Russia in Table 2 is for 1870.

${ }^{12}$ US Department of Labor, Fifteenth Annual Report. The US data includes 1900; other countries until 1899. I have dropped the 1900 observations for the US.
} 
combined about 45-50 percent). The appendix contains definitions of the sectors, as well as a regional breakdown of the US data.

The workday was very long, about 12 or more hours in many sectors and countries since there was no Sunday work. ${ }^{13}$ They were generally longer in services and textiles than in manufacturing and iron and steel. There is no discernible pattern to women's work. Time trends are more difficult to detect because missing observations plague the data set. To get around this problem, Table 4 presents quinquennial averages. Some countries, like Germany and Switzerland exhibited a large decline in hours; others, like Belgium and Denmark, saw an initial rise, then a decline; finally, for a group of countries, including Canada and Italy, there was little or no trend in worktime. National work routines explain some of these patterns. In France, the trend was indeterminate, a result that meshes with the depictions of social historians. Up until the First World War, the workweek was haphazard and the notion of the weekend ill defined. ${ }^{14}$ For developing countries catch-up - the race to the top - was laborious, since Britain, the European leader, was a moving target, its hours falling only slightly less than the Old World average. To be sure, this portrait is imperfect, because for certain countries observations tend to be concentrated in selected periods. A compounding problem with the survey is that sectors were not sampled evenly across sub-periods. I will attempt to correct for these problems in the next sections of the paper. That said, in the case of the Netherlands, a country which had a very long workweek, the number of observations is spread out equally, while for Belgium, the long work hours in 1880-84 do not seem unrepresentative because of the relatively large number of observations in the subperiod.

Independent sources confirm the results of Tables 3 and 4. The British, Canadian, Dutch, French, German and US series from the Department of Labor survey correspond closely with other, albeit scattered, estimates. ${ }^{15}$ There are differences between the new figures and previous estimates for Belgium, Denmark and Italy. ${ }^{16}$ In the case of Belgium, my series indicates shorter working hours than Scholliers found in his study of a single textile enterprise, but this is consistent with the general result of longer than average work hours in the textile sector. The

\footnotetext{
${ }^{13}$ The consular reports confirm that these hours were net of meal and rest times. Even if rest time is excluded in these figures, there is a potential bias in the other direction. The Department's report contains no mention of overtime hours. Contemporary sources indicate that at certain times of the year these may not have been negligible. Because of the possibility of opposing biases due to the exclusion of rest times and overtime, I have left the raw series unadjusted. For contemporary accounts, see: Cross, Quest for Time, pp. 67, 234; Gårdlund, Industrialismens, p. 312; Heikkinen, Labour and the Market, pp. 154-56; Kaplow, "Saint-Lundi"; Pollard, "Labour in Britain," pp. 157-58; Rist, La réglementation légale, pp. 177-88; Rosenband, Papermaking, p. 108;

${ }^{14}$ To the French, the six-day work week was la semaine anglaise. Cross, Quest for Time, pp. 79-102.

${ }^{15}$ Great Britain: Bienefeld, Working Hours; Matthews, Feinstein, and Odling-Smee, British Growth, pp. 64-70, 566; Canada: Altman, "New Estimates," p. 361; France: Marchand and Thélot, Travail en France, p. 145; Germany: Hoffmann, Wachstum der deutschen Wirtschaft, pp. 213-14; Netherlands: Wintle, History of the Netherlands, p. 66; US: Atack and Bateman, "How Long was the Workday," p. 139; Costa, "Wage and Length," p. 158.

${ }^{16}$ Belgium: Scholliers, Wages, Manufacturers; Italy: Federico, L’Industria mondiale.
} 
average hours in Denmark is about one-half hour per day more longer than that reported by J. P. Christensen. ${ }^{17}$ Still, as late as the 1890 s, contemporaries reported that in Copenhagen " 89 percent of all factories had a working day of ten-and-a-half hours or less, whereas in the provinces a large number of establishments visited worked 11 hours or more." 18 My figure for Denmark at the end of the century is not far off the mark.

\section{Annual worktime and standard explanations}

There are several problems in calculating annual worktime measures from the data set, owing to its unbalanced nature over time and across sectors. Consider the sectoral balance. The number of hours worked per week in the first column of Table 3 is an unweighted average. The heavy representation of the textile sector does not correspond to its share of the labor force, about 10 to 20 percent of paid workers many countries. In contrast, the share of services is underrepresented. Services, broadly defined, amounted to between 25 to 50 percent of the labor. But since work hours in services were in fact longer than those in textiles, reweighting the sectoral components would only increase the average length of the workweek.

Recognizing the data limitations, Table 5 collects information from the consular reports and the Department of Labor survey, and other sources, to estimate annual work hours for Old and New World countries. The number of days worked per year is taken from Table 2 and hours per week from Table 3. ${ }^{19}$ Using information from the Department's study of health insurance, I have deducted from the former series the number of day's loss due to illness. ${ }^{20}$ I have not made any deductions for average days loss due to unemployment or for work stoppages. Although some national series exist for these measures, further research is needed to make them comparable across countries. The resulting series in column 5, therefore, represents potential worktime. Again, independent sources verify my procedures. The figure for France is just slightly higher than the 3,045 hours calculated from a survey conducted by the Office du travail in 1891, while that for the US approximates the 3,200 hours calculated from recent studies. ${ }^{21}$

These new figures confirm the impression that a long work year was the rule in the in both the Old and New World. The exception was Australia, which must have appeared to a northern

\footnotetext{
${ }^{17}$ Christensen, Lønudviklingen inden, p. 71.

${ }^{18}$ UK PP 1893-94 XXXIX, Part II, p. 780. Workdays of 12 hours were reported for Norway and Sweden in the 1890s. Ibid., pp. 778-79.

${ }^{19}$ Compared to Maddison's approximations, this amounted to slightly fewer days of work per year and more days lost.

${ }^{20}$ US Department of Labor, Twenty-Fourth Annual Report, and Workmen's Compensation Laws. I would like to thank John Murray for recommending this source.

21 Decouflé and Svendsen, "Une histoire." For the US, Atack, Batemen, and Margo ("Productivity in Manufacturing") reported 309 days of work and 60.5 hours per week. Rosenbloom ("Male Labour Supply") assumed 306 days of work.
} 
European laborer as a worker paradise. There was an 800 hours difference between Australia and the Netherlands. This is comparable to the gap in 1998 between Mexico, which had perhaps the longest work year among developing countries, and the Netherlands, which had the shortest work year in the club of advanced economies. ${ }^{22}$ Columns 6 and 7 calculate annual work hours at the beginning and end of the period using data from Table 4 and assuming the same workweek and days of work as in column 5. Evidence of convergence is mixed. The gap between the US and Denmark narrowed by 180 hours over the thirty year period; but the overall difference between New and Old World hours fell by only 50 hours, while the standard deviation and the coefficient of variation for Old World (European) countries actually increases. ${ }^{23}$

The differences in work hours affected the relative standards of living of countries. In the Appendix, I calculate GDP per capita adjusted for changes in leisure. This expanded indicator of well being reveals a larger gap between Britain and elsewhere than conventional measures of income have found. The new annual numbers also have implications for standard readings of international productivity levels and changes. Based on Maddison's numbers, GDP per worker hour converged between 1870 and 1914. Recall, however, that Maddison assumed the same hours across countries in his data set. Using the revised numbers, the Appendix shows that productivity levels in Britain were higher and the gap between it and its rivals much larger.

The general portrait of work hours from the tables raises some doubts with conventional explanations of the length of the workday. The common demand side argument is that the workday was long because employers sought to extend the utilization of their fixed capital investments. ${ }^{24}$ But the sectoral breakdown indicates that in all countries hours were in fact shorter in capital-intensive sectors, like construction and mining and iron and steel, than in services and manufacturing. As for supply, the annual measures cast some doubt on the textbook view that as the wage rises, the income effect dominates the substitution effect. Voth found that English laborer spent roughly 3,300 hours at work in 1830 , close to the worktime of a Dane in $1870 .^{25}$ Denmark's per capita income in the latter year was nearly $\$ 2,000$, around the level of British income in $1830 .{ }^{26}$ Over time, as income levels increased - average GDP per capita increased by 50 per cent from 1870 to 1900 for the group of countries in this paper - work hours ought to have

\footnotetext{
${ }^{22}$ The last column of Table 5 gives 1998 annual hours. The decline of work hours over the last century, much of which took place between 1920 and 1950, was as striking as it was universal. For an analysis, see, Crafts, "Human Development Index."

${ }^{23}$ The coefficient of variation tests for sigma-convergence. I have also tested for beta-convergence in regressions with annual work hours in 1870 and the rate of change in worktime form 1870 to 1899 as dependent and independent variables. For both Europe and all countries, the regressions performed poorly. These measures of convergence give only a partial view of the dispersion of worker welfare. Presumably, workers were concerned with the combination of hours supplied and wages earned. The Department's report gave evidence of wages along with hours and in a companion article I examine the two together.

${ }^{24}$ For this view, see Clark, "Factory Discipline."

${ }^{25}$ Voth, Time and Work, p. 258.

${ }^{26}$ All GDP per capita figures in 1990 international dollars. Source: Maddison, Monitoring, and World Economy.
} 
fallen. Figure 1 traces the correspondence between worktime and income for all countries in our sample, combining information for 1870 and 1899. The overall relationship is downward as expected, although it is barely significant. Table 6 reports the estimated coefficients of regressing hours on GDP per capita, with population as a control variable. ${ }^{27}$ GDP per capita is significant only when the New World countries are included in the sample (regression 1). European countries seem to have had their own dynamic. Undoubtedly, these results suffer because of the small sample size and from the problems inherent in calculating annual hours. The results may indicate as well that there are variables omitted. In the next section, I treat these problems in more detail.

In Figure 1, the Netherlands in 1899 is a clear outlier. ${ }^{28}$ Dutch hours actually rose over the period even as income levels increased by a third. Sui generis, the Dutch case merits further explanation because it resembles the relation between work hours and consumption, the industrious revolution, Jan de Vries found for an earlier period. ${ }^{29}$ Real wages in the Netherlands were depressed in the first half of the nineteenth century, but relative to labor costs of its continental neighbors, they proved to be an obstacle to prolonged growth. After 1870 or so, the long-term decline in prices of grain imports caused a steady rise in real wages. Calorie intake increased from about 2,000 units in 1870 to nearly 2,800 by the First World War - about 300 units more than the British consumed at the time -, and there is little evidence that the condition of the Dutch working class deteriorated in the period. ${ }^{30}$ The increase in labor input is consistent with this picture. ${ }^{31}$ Sustained by higher food intake, workers supplied more hours on the job. Voth has attempted to modify the basic relation between income and hours. He argued that the transfer of technology from the industrial leader to developing countries, and the accumulation of human capital, reduced the demand for labor input. Britain's long work hours between 1780 and 1830 were an exception, the penalty of being an early industrializer. Using Maddison's data for OECD countries, 1870 to 1987, Voth reported a negative and significant relation between the gap in GDP per capita, the difference in income between the leader and that of other countries, and annual worktime. But the last two columns of the table show that Voth's prediction does not stand up for 1870-99, either for the entire sample or for European countries only.

In sum, the worktime measures from the original sources I have consulted indicate that work hours were very long in European countries in the last three decades of the nineteenth century, much longer that it would be expected given their levels of income. Because hours did

\footnotetext{
${ }^{27}$ The regression models follow Voth, Time and Work, pp. 253-68. A log specification does not change the results in any significant way.

${ }^{28}$ This paragraph is based on Wintle, History of the Netherlands, and van Zanden "Industrialization."

${ }^{29}$ de Vries, "Industrial Revolution."

${ }^{30}$ Wintle, History of the Netherlands, p. 65; Clark, Huberman, and Lindert, "British Food Supply," p. 223.

31 The increase in labor input corroborates Rees' claim (footnote 1 above) on workers' potential to supply very long hours of labor, at least over a short period, without detriment to productivity or welfare.
} 
not always move in the opposite direction to income, convergence in worktime between Europe and the New World was slow. In the next section of the paper I explore in detail whether these results hold when I control for country and sector.

\section{Trends in worktime: national routines and international pressures}

Even if workers desired to reduce hours as their incomes rose, they did not necessarily have the capacity to do so over the short term. In general, individual workers have only partial recourse to negotiate their work hours, which are a type of public good fixed by collective decision making. ${ }^{32}$ In the absence of unions, workers were easily divisible and employers got their way in extending the length of the workday. Beinefeld used this type of reasoning to explain why British hours did not fall continuously as incomes rose in the late century. An alternative was government intervention. In Switzerland, working hours fell abruptly in the mid 1870s, and the decline coincided with new laws that prohibited night work of adolescents, restricted women's work, and that fixed the length of the workday of all workers at 11 hours. The Swiss were way ahead of the rest of Europe. It was only in the late 1890s that most countries had limitations on night work for women and children, and a smaller group had fixed the length of the workday of women at 11 hours. ${ }^{33}$ Elsewhere in Europe, enfeebled by their limited representation in national assemblies and parliaments, workers' fate was in the hands of social reformers and liberals. But although there was near unanimity on setting standards for the working conditions of children, and to some extent women, men's hours proved more contentious. To some, men ought to have the freedom to contract their work as they saw fit, and anyway evidence that long hours hampered productivity was mixed. Restricitng the workday reduced employment because it raised labor costs. The workday would fall with improvements in productivity. Others believed that fixing the workday was in everyone's best interest with few ramifications on productivity and income.

Often inconclusive, these debates were more successful in shedding light on what contemporaries perceived to be the determinants of national and global trends in worktime. Typical was the view of Charles Rist, the French economist and social reformer, who divided the French economy into two sectors: a sector composed of industries producing for the home market and, a second, comprised of firms facing stiff international competition. ${ }^{34}$ In the non-tradeable goods sector, Rist observed, hours were set by a combination of social factors, such as local and regional work routines, and economic forces, like productivity and income improvements. They could be long or short depending on the relative importance of these factors. The state could limit

\footnotetext{
${ }^{32}$ On hours as a public good, see Huberman, Escape from the Market, pp. 123-24; Shiells, "Collective Choice."

${ }^{33}$ For countries and dates of introduction of factory legislation, see Huberman and Lewchuk, "European Economic Integration.” For Switzerland, see Follows, International Labour.

${ }^{34}$ Rist, La réglementation légale.
} 
the workday of firms in these industries without affecting the external balance. But Rist did not advise restrictions in the export or competing-goods sector. Limiting the workday to 10 hours would make the French silk industry uncompetitive with that of Italy, and the hexagon's ribbon and lace manufacturers suffer at the expense of the Swiss and Germans.

To fix ideas, consider that a combination of economic, and country specific and industry (or sectoral) factors determine work hours. I am interested in the effect of the addition of country and industry factors to the simple specification underlying Table 6 in which income determines hours only. Country factors include long-standing work routines and legal restrictions on the workday. Industries can arranged by their degree of international exposure. The textile sector faced the highest degree of international competition, followed by manufacturing, iron and steel, mining and construction, and services. ${ }^{35}$ In light of Rist's classification, two types of regimes or spheres coexisted. In non-competing sectors national routines dominated, hours were variable across countries owing to the mix of legal and social factors, and convergence was weak. In the other, industries faced stronger international competition, hours were long and there was a tendency to convergence because of the potential of a race to the bottom. The balance of forces between country and sectoral factors would explain the weak results regarding convergence reported in the previous section.

Table 7 presents tests of these propositions using all the observations on weekly work hours from the survey and gets around the aggregation problems inherent in constructing annual measures of work time. The first regression reports that the length of the work week was in fact negatively related to GDP per capita, as theory would expect. ${ }^{36}$ Regression two adds country factors, with Great Britain as the baseline case. An F-test rejects the hypothesis that the addition of country factors had no effect on work hours. Holding income levels constant, there were significant differences between countries. Britain was comparable only with Ireland and Canada, and most pair wise comparisons reject the null hypothesis of no difference between countries. ${ }^{37}$ Although extreme, the Belgian case - of the 12 pair wise comparisons the hypothesis of no difference is rejected in all cases - is instructive. Workers lacked a collective voice and, as a result, Belgian employers had the upper hand, refusing any concession on working conditions. Labor legislation of any note had to wait until the early twentieth century when workers gained a legitimate presence with the introduction of proportional representation in the national assembly.

\footnotetext{
${ }^{35}$ As defined (see Appendix), iron and steel products and manufacturing goods were exported, but mainly to niche markets. Mining and construction output was not traded, except for coal.

${ }^{36}$ So as not to overwhelm the data set, a 10 percent random sample $(\mathrm{N}=1570$, selected according to the SPSS procedure) of US observations was used in the panel regressions of Table 7. The mean (s.d.) of the sample is 60.31 (5.6). The Swedish and Danish observations were combined in Scandinavia. In other regressions, not reported, I included a time variable, and $\mathrm{GDP}^{2}$. The estimated coefficients were generally insignificant.

${ }^{37}$ Voth using aggregate series rejected the hypothesis of British exceptionalism.
} 
The third regression examines the impact of sectors, with manufacturing as the baseline case. Again, an F-test rejects the null of no added effect. As a whole, sector was less important than country, adding 8 percent to the explanatory power of regression 1, while country contributed 25 percent. ${ }^{38}$ That said, the sectoral dummies conform to Rist's insights. Compared to manufacturing, hours were longer in textiles and shorter in mining and construction. The service sector had the longest hours, but its products, like haircuts, were not traded; the length of the working day in this sector may have been the result of the loose industrial organization of firms and variable demand for their products. Similar differences between sectors and countries are also found when these variables are estimated together in regression 5.

The German case illustrates the possibility of interaction between sectoral and country factors. To get work hours down, Bismarck used a policy of tariffs as an alternative to labor market regulation. "A normal workday could be established for Germany alone if Germany were surrounded by a Chinese wall and were economically self-sufficient." 39 As elsewhere, German tariff policy impacted on sectors unevenly, and this likelihood can be handled by adding interaction variables. ${ }^{40}$ But inspection of the error terms in the regressions with country variables indicated the presence of heteroscedasticity, resulting, perhaps, from different data collection methods across countries. Moreover, regressions 4 and 5 in Table 7 assume that the relation between sectors was the same in all countries, and all regressions assume that there are no country specific GDP effects. To get around these problems, Table 8 reports regression results for countries with more than 100 observations separately. ${ }^{41}$ The specificity of the textile sector is apparent. In six countries textiles are different from manufacturing, and in eight from mining and construction. Clearly, across Old and New Worlds, holding income levels constant, the textile industry was under different pressures than found in other sectors where national routines remained the dominant influence on the workday. Germany was an exception. It had a large textile industry, but tariff protection seems to have isolated it from pressures elsewhere, and worktime in this sector was no different than in manufacturing, iron and steel and services. The overall results are corroborated in Table 9 which breaks down the determinants of work hours by sector. Here I compare the determinants of hours in textiles and in mining and construction only, adding a time variable and an interaction term between time and GDP per capita. After controlling for country effects, the time coefficient is negative and significant for the textile

\footnotetext{
${ }^{38}$ This is only an illustration of the explanatory power of country and sectoral factors because the regressors are not orthogonal.

${ }^{39}$ Bismarck responding in 1885 to demands by social reformers to improve working conditions, as cited in Follows, International Labor Organization, p. 91.

${ }^{40}$ The $\mathrm{R}^{2}$ of regression 5 of Table 7 with interaction terms is .533, indicating little effect from their addition.

${ }^{41}$ These regressions also included a constant and a binary variable for sex. The estimated coefficients are not reported and are available upon request.
} 
sector, while GDP is insignificant; in mining and construction the reverse holds. ${ }^{42}$ My interpretation of these results is that in the competing-goods sector there was a common trend in work hours across countries, but national specific factors mattered more elsewhere.

\section{Textile workers of the world unite!}

Gregory Clark has argued that productivity differences in the international textile industry before 1913 were substantial, an outcome that he speculated was due to "local effects" - by which he meant the culture of the indigenous labor force. ${ }^{43}$ In this perspective, British producers had little to fear from foreign competition because long work hours elsewhere reflected low productivity. Clark may be right comparing Britain and India, but there is other evidence to suggest that he may have underestimated competition on the continent. D. A. Farnie, the doyen of cotton historians, wrote that British market penetration in Europe reached its peak by the early 1880s. ${ }^{44}$ The French, Belgian and, increasingly, Italian industries had successfully challenged British supremacy. Even the hard working Dutch had captured an increasing share of their home market. $^{45}$

The explicit motivation behind the consular reports was to get a better understanding of the sources of competitive advantage of Britain's major rivals. In 1870, the consular delegate in Belgium calculated that labor costs in Britain were competitive despite low wages and long hours of work on the continent. Still, the consular reports raised the specter that in the future Lancashire employers would be hardpressed to make further cuts to working hours, if Belgian levels failed to approach those in Britain. ${ }^{46}$ By the 1890 s, as continental hours remained stubbornly long, these concerns became the lighting rod of trade union activists who, fearing a race to the bottom, called for international standards that would lower work hours and raise working conditions on the continent. At home, Lancashire workers withdrew their support for more restrictions on the length of the workday. The upshot is that contemporaries perceived that the length of the workday was a potential source of comparative advantage.

\footnotetext{
${ }^{42}$ F-tests for equality among countries give further support to the impression that international forces dominated national practices in the textile sector. For the textile sector, based on regression 1 in Table 9, the hypothesis that France $=$ Germany $=$ Italy cannot be rejected; for mining and construction, the hypothesis is rejected.

${ }^{43}$ Clark, "Why Isn't the World Developed."

${ }^{44}$ English yarn exports "reached successive peaks to Germany in 1872 , to Italy in 1876 , to Belgium in 1878 , to Russia in 1879, and to France in 1883. The watershed in the history of the trade occurred in 1884 when the volume of yarn exports to both Europe and Asia reached its all-time maximum." Farnie, English Cotton, p. 183.

${ }^{45}$ Van Zanden, "Industrialization," p. 89.

${ }^{46}$ On the consular reports and international competition in textiles, see Bruland, "The European Textile Industry." Other industries faced similar competitive pressures. Even as early as 1870, correspondents reported that the "way to combat competition from abroad in the tobacco and cigar industry...[was] for English working men to consent to a diminution of the[ir] high rate of wages...or [to] a proportionate increase in hours." UK PP 1871 LXVIII, pp. 62-63.
} 
Tables 10 and 11 give trends in the basic data on textile hours and cotton consumption per capita to investigate contemporary concerns. Over the thirty-year period, the average decline was practically insignificant (Table 10 last line). Spanish and French hours actually increase, while for some of the leading industrializers, the decline in textile work hours was smaller than their general 1 averages. In Britain, textile hours declined by 4.7 percent, but average hours by 8.2 percent. In Italy, the decline of 5.1 percent in textiles was greater than the fall in the national average, and by the end of he period its workweek was identical to that of France, the Netherlands, Spain, and Switzerland The net result was both a decline and convergence of work hours, thereby explaining the negative time coefficient in Table 9. The coefficient of variation for the entire sample of textile hours falls from 0.85 in 1870-79 to 0.69 in 1890-99. Recall that there was no tendency for average hours to converge (Table 4). Table 12 gives raw cotton consumption per capita over the period. If contemporary concerns about the sources of competitive advantage were justified, textile hours would have been responsive to the relative importance of the industry. The Swiss and Italian cases stand out. The former ran down its industry as it sought to specialize in other export industries that were better suited to its level of development and factor endowments, and, as a result, its hours fell by more than the European average. The Italians promoted the expansion of textile production, consumption of cotton tripled and the decline in work hours much smaller.

It may have been the case that other factors, besides international pressures, were responsible for the apparent convergence of worktime in textiles. Although I cannot reject this hypothesis, I can confirm whether textile hours were in fact a source of comparative advantage. Here I follow the procedure and specification set out by Dani Rodrik in his study of hours in the international textile industry in the last quarter of the twentieth century. ${ }^{47}$ For a cross section of countries, Rodrik regressed the share of textile exports in total exports on a measure of the quality of the labor force and the labor-land ratio. He found, as trade theory would predict, that textile exports were larger in countries with less skilled workers and where the ratio of workers to land was high. Regression 1 in Table 12 shows that the relation between factor endowments and cotton textiles held as well in late nineteenth-century Europe. The dependent variable here is the annual change in per capita consumption of raw cotton, which is correlated with the available data on the change in countries' export position. ${ }^{48}$ Rodrik added the level of hours to this basic model and found that, across countries, the longer the workweek the greater the proportion of textile exports. Regression 2 using evidence on weekly hours shows that this was also the case in Europe one hundred year earlier. The coefficients have positive signs and are significant. The last regression adds a binary variable for labor legislation, equal to one for countries that had some minimal

\footnotetext{
${ }^{47}$ Rodrik, "Labor Standards."

${ }^{48}$ Robson, Cotton Industry, pp. 332-59.
} 
restriction on work hours. ${ }^{49}$ The sign is negative, corroborating Rist's claim that limiting work hours would have only damaged the expansion of France's cotton textile sector. In all, these results give support to the view that, as today, long hours were a source of competitive advantage and not a sign failure or inefficiency as Clark asserts. The perception that Lancashire workers marched to Italian time had merit.

\footnotetext{
49 The countries and dates were: Britain and Switzerland, from 1870; Germany and France, from 1890. Source: Huberman and Lewchuk, "European Economic Integration."
} 


\section{Concluding observations: globalization then and now}

\section{Pain in Spain: Workers bid adios to siesta}

With Spain under pressure to adjust to richer neighbor's timetables, the ritual three-hour break for lunch and nap is disappearing. Spaniards say that they are working harder these days and sleeping less, feeling at once more prosperous and more fatigued....Because of more industrious work habits, according to one nationwide survey, regular siesta takers [now constitute only] 24 per cent of the population...The siesta is losing ground in other Mediterranean strongholds as Portugal, Italy and Greece also rush to catch their partners in the European Union.

Los Angeles Times March 31, 2000

Between 1870 and 1913, the transport revolution and population and capital movements brought Old and New Worlds closer together. Economic historians, led by Williamson, have investigated the effects of globalization on factor prices, which are believed to have converged across continents. The expansion of international exchanges also impacted on convergence within Europe. Sidney Pollard, for one, has written that after 1870, the European membership in the club of industrializers expanded. ${ }^{50}$ But how deep was convergence? Did commodity and factor-ofproduction flows erode differences in living standards - broadly defined to include wages and hours - between continents and national economies?

This paper has sought to show that although globalization was extensive, convergence was limited. To begin, prevailing interpretations of movements in productivity and income stand to be corrected because they are based on Maddison's data set on worktime which is seriously flawed. New international evidence demonstrates that work hours and days varied between countries, as well as between continents. Across the sample, hours generally did decline with income, a response that should have led countries to look more and more alike. This was not evident and not simply because countries moved in the same direction, albeit at different rhythms. Some, like the Netherlands, moved entirely in a different direction. National work routines persisted in the period, while other countries differed because of varying degrees of restrictions on the workday. Sectoral factors contributed as well to trends in international worktime. With rising levels of income, hours across countries should have exhibited a race to the top. But in the competinggoods industries, like textiles, the opposite took hold. Because hours were a source of competitive advantage, even the British had to keep in time with the Italians. As a result of the mix of economic, national and sectoral factors, trends in worktime did not behave as factor prices did.

\footnotetext{
${ }^{50}$ Pollard, Peaceful Conquest.
} 
These findings cast some light on opposing views on the effect of economic integration on worktime. One view is that as global forces spread and accentuate, combined with the process of harmonization embedded in projects like the European Union, the workday will tend to look alike across countries, and even Spanish workers will lose their rest time. The other is that there are many margins of adjustment in labor markets, and because the non-tradable sector remains important, pressures on labor costs need not translate into convergence of worktime. ${ }^{51}$ My results give support to both positions, but the balance tilts toward the claim that national work routines can be preserved. The Swiss case exemplifies this possibility. The country remained open throughout the late nineteenth century and at the same time introduced progressive labor legislation reducing the length of the workday. It did so only because it moved out of textile manufacture. In countries that were less flexible, workers' leisure time was compressed. Where policy is farsighted, workers can indeed enjoy the benefits of globalization and keep their siesta too.

${ }^{51}$ Ehrenberg, Labor Markets, provides a summary of the debate. 


\section{APPENDIX}

\section{A1. The data source}

In its $15^{\text {th }}$ Annual Report, the US Bureau of Labor gathered data on factory condition across countries, including the weekly hours and earnings of female and male workers, and occasionally of the size of firm. The unit of observation was occupation (the average hour worked by a cotton spinner in a particular firm and year). Table A1 gives the breakdown of the 46 occupations by sector.

\section{A2. The US data}

In its report, the Bureau of Labor appears to have assembled all previous published census returns, and state and federal bulletins and reports on work hours. Rosenbloom, and others have used these earlier studies, and my findings closely resemble their results. ${ }^{\mathbf{5 2}}$

\section{A3. Worker welfare}

It is well known that GDP per capita underestimates workers' welfare because it does not include gains to workers owing to increased leisure time. Fewer hours worked by the employed implies greater leisure, which presumably adds to workers' utility. This is not true for the unemployed or for those working fewer hours than they would like to. Still, standard neo-classical analysis suggests that adults in countries with fewer hours worked will be better off relative to those in countries with more hours worked at the same level of GDP per capita. This implies that units like Britain were in fact relatively better off after controlling for hours worked. To get an idea of how much better, I follow a standard approach and measure leisure-adjusted income in period $t$ as the sum of income in period $t$ and the difference in hours worked between $t$ and the base year 0 , valued at the wage rate in $t .{ }^{53}$ Because it is unclear if existing wage series take into account hour changes, I use GDP per capita. ${ }^{54}$ For Belgium, Table A3, reports GDP per capita of $\$ 3,579$ in 1899 and a decrease of 119.9 hours per person between 1870 and 1899. Assume, following N.F.R. Crafts, that labor's share of income was 70 percent; the gain in leisure is $0.7 \times 2.72$ per hour (GDP/per hour worked in 1899) x $119.9=\$ 227$. Thus, leisure-adjusted GDP per capita is $\$ 3,806$ (last column of the table). Britain's position does improve relative to the European average. The welfare of Swiss and Belgian workers is now greater than that of the Dutch, and the

\footnotetext{
${ }^{52}$ In Table A2, I have organized the US data by region, following the division of states in Rosenbloom, "Was There a National Labor Market," p. 653.

${ }^{53}$ I have followed the procedure set out in Beckerman, "Comparative Growth Rates," and Crafts, "Human Development Index." See, Bell and Freeman, "Americans and Germans," for similar calculations for the period after 1945

${ }^{54}$ Williamson ("Evolution of Global Labor Markets") sought to construct a series of real wages for comparable periods of work time, but owing to data limitations he was not completely successful. Of the European wage observations in the Williamson data set for the period between 1850 and 1914, nine percent reflect earnings per hour, 23 percent daily earnings, 16 percent weekly earnings and 11 percent monthly or annual earnings; 40 percent of all observations are unspecified. For example, the wage series for Sweden is inferred from an annual index. It is not evident to what extent the index captures changes in work hours. O'Rourke and Williamson, Globalization and History, found that convergence in GDP per capita generally understates real wage convergence.
} 
gap between German and French workers is twice as large when using leisure-adjusted GDP. There is little evidence of convergence. While the coefficient of variation of GDP per capita (uncorrected) falls from 1870 to 1899 , there is no change in dispersion when comparing 1870 value with 1899 leisure-adjusted GDP per capita.

\section{A4. Productivity}

Maddison assumed uniform weekly work hours across the New and Old Word to calculate GDP per hour worked, his preferred measure of productivity. In Table A4, I present Maddison's figures for 1870 and 1900, along with my new estimates for 1870, 1899, and 1913 based on the evidence from the report. (The 1913 estimate assumes 1899 work hours.). All calculations use the same GDP values and labor force numbers. For the entire sample, average productivity levels and changes over time are about the same comparing Maddison and the revised measure, but the relative positions of the countries differ. Using the new work hour estimates, British productivity levels in the last three decades of the century were higher, by about 8 percent in 1899 , and while Maddison's figures indicate that leadership passed to the US at the turn of the century, the revised estimates still give Britain the advantage at this date. The gap between Britain and its continental rivals (the Old World average) actually increased between 1870 and 1899. There are differences in productivity changes as well. Compared to Maddison, the new estimates show stronger productivity growth in Australia, Denmark, Germany, Spain and Switzerland, slightly poorer performances in Canada, Italy, Sweden and the US, and much poorer performances in France and the Netherlands. With regard to convergence, Maddison's numbers show a closing of the productivity gap between Old and New World between 1870 and 1900; the corrected estimates show that the gap actually widened. 
TABLE 1

MADDISON'S ESTIMATES OF WORKTIME, 1870-1913

\begin{tabular}{|c|c|c|c|c|c|c|c|c|}
\hline & \multicolumn{3}{|c|}{ Hours of work per week } & \multicolumn{2}{|c|}{ Weeks of work } & \multicolumn{3}{|c|}{ Annual hours of work } \\
\hline & 1870 & 1900 & 1913 & 1870 & 1913 & 1870 & 1900 & 1913 \\
\hline Austria & 63 & 56.3 & 53.8 & 50.3 & 49.3 & 2935 & 2679 & 2580 \\
\hline Belgium & 63 & 56.3 & 53.8 & 51.0 & 50.0 & 2945 & 2707 & 2605 \\
\hline Denmark & 63 & 56.3 & 53.8 & 50.3 & 49.3 & 2945 & 2688 & 2588 \\
\hline Finland & 63 & 56.3 & 53.8 & 50.3 & 49.2 & 2945 & 2688 & 2588 \\
\hline France & 63 & 56.3 & 53.8 & 50.3 & 49.3 & 2945 & 2688 & 2588 \\
\hline Germany & 63 & 56.3 & 53.8 & 50.3 & 49.3 & 2941 & 2684 & 2584 \\
\hline Great Britain & 63 & 56.3 & 53.8 & 51.0 & 50.0 & 2984 & 2725 & 2624 \\
\hline Italy & 63 & 56.3 & 53.8 & 49.3 & 48.3 & 2886 & 2634 & 2536 \\
\hline Netherlands & 63 & 56.3 & 53.8 & 51.0 & 50.0 & 2964 & 2707 & 2588 \\
\hline Norway & 63 & 56.3 & 53.8 & 50.3 & 49.3 & 2945 & 2688 & 2605 \\
\hline Sweden & 63 & 56.3 & 53.8 & 50.2 & 49.2 & 2945 & 2688 & 2588 \\
\hline Switzerland & 63 & 56.3 & 53.8 & 51.0 & 50.0 & 2984 & 2725 & 2624 \\
\hline Australia & 63 & 56.3 & 53.8 & 50.7 & 49.7 & 2945 & 2688 & 2588 \\
\hline Canada & 63 & 56.3 & 53.8 & 50.7 & 49.7 & 2964 & 2707 & 2605 \\
\hline United States & 63 & 56.3 & 53.8 & 50.7 & 49.7 & 2964 & 2707 & 2605 \\
\hline Europe & 63 & 56.3 & 53.8 & 50.4 & 49.4 & 2947.0 & 2691.8 & 2591.5 \\
\hline New World & 63 & 56.3 & 53.8 & 50.7 & 49.7 & 2957.7 & 2700.7 & 2599.3 \\
\hline
\end{tabular}

Sources: Maddison, Economic Growth, Phases of Development, Monitoring, World Economy 
TABLE 2

WORKTIME AROUND THE WORLD

\begin{tabular}{|c|c|c|}
\hline & $\begin{array}{c}\text { Work hours } \\
\text { per day }\end{array}$ & $\begin{array}{c}\text { Work year } \\
\text { (days) }\end{array}$ \\
\hline Austria & 12 & 289 \\
\hline & & 308 (1913) \\
\hline Belgium & 13 & $\begin{array}{c}284 \\
292(1892)\end{array}$ \\
\hline Brazil & 10 & \\
\hline Canada & 10 & 305 \\
\hline Chile & & 298 \\
\hline Denmark & 12 & 310 \\
\hline Ecuador & 9 & \\
\hline Finland & 11 & 288 \\
\hline France & 12 & $\begin{array}{c}264 \\
293(1887)\end{array}$ \\
\hline Germany & 12 & \\
\hline Great Britain & 10 & 299 \\
\hline Greece & 12 & 170 \\
\hline Italy & 11 & $\begin{array}{c}270 \\
290(1892)\end{array}$ \\
\hline Lebanon & 13 & \\
\hline Morocco & 10 & \\
\hline Netherlands & 13 & 310 \\
\hline Norway & 13 & \\
\hline Poland & & $230(1890)$ \\
\hline Portugual & 12 & 301 \\
\hline Puerto Rico & 10 & \\
\hline Russia & 12.5 & 288 \\
\hline Spain & 11.5 & 282 \\
\hline Sweden & 13 & 305 \\
\hline Switzerland & 13 & 310 \\
\hline United States & 10.5 & 309 \\
\hline
\end{tabular}

Note: All figures are for 1870 except where indicated.

Sources: PP 1870 LXVI, PP 1871 LXVIII, PP 1872 LXIII, PP 1893-94 XXXIX, PP 1899 XCII. 
TABLE 3

AVERAGE HOURS OF WORK PER WEEK, 1870-1899

(Number of observations)

[percentage]

[s.d.]

\begin{tabular}{|c|c|c|c|c|c|c|c|c|}
\hline \multicolumn{9}{|c|}{ Hours of work per week } \\
\hline & All & Men & Women & $\begin{array}{l}\text { Mining and } \\
\text { construction }\end{array}$ & Iron and steel & Textile & Manufacturing & Service \\
\hline \multirow[t]{2}{*}{ Belgium } & $67.7(172)$ & $67.5(136)$ & $69.9(22)$ & $65.9(42)$ & $68.1(43)$ & $70.5(55)$ & $63.4(22)$ & $68.6(10)$ \\
\hline & [5.9] & [86.1] & [13.9] & {$[24.4]$} & {$[25]$} & {$[32]$} & {$[12.8]$} & {$[5.8]$} \\
\hline \multirow[t]{2}{*}{ Denmark } & $62.0(46)$ & $61.8(40)$ & $69.5(2)$ & $61.6(11)$ & $61.8(9)$ & $63.3(3)$ & $62.2(18)$ & $61.8(5)$ \\
\hline & {$[6.0]$} & [95.2] & [4.8] & [23.9] & [19.6] & {$[6.5]$} & [39.1] & [10.87] \\
\hline \multirow[t]{2}{*}{ France } & $65.2(650)$ & $65.0(478)$ & $65.5(105)$ & $62.7(154)$ & $65.2(142)$ & $66.8(197)$ & $66.3(107)$ & $70.6(50)$ \\
\hline & [5.5] & [82.0] & {$[18.0]$} & [23.7] & {$[21.8]$} & {$[30.3]$} & {$[16.5]$} & [7.7] \\
\hline \multirow[t]{2}{*}{ Germany } & $65.4(672)$ & $65.5(468)$ & $65.1(56)$ & $62.1(141)$ & $65.3(153)$ & $66.4(142)$ & $66.3(182)$ & $68.1(54)$ \\
\hline & [7.2] & [89.3] & {$[10.7]$} & {$[21.0]$} & {$[22.8]$} & [21.1] & {$[27.1]$} & {$[8.0]$} \\
\hline \multirow[t]{2}{*}{ Great Britain } & $55.0(2447)$ & $54.9(2117)$ & $56.6(194)$ & $54.6(893)$ & $56.7(614)$ & $56.3(475)$ & $54.5(384)$ & $68.6(81)$ \\
\hline & {$[5.0]$} & [91.6] & [8.4] & {$[36.5]$} & {$[25.1]$} & {$[19.4]$} & [15.69] & {$[3.3]$} \\
\hline \multirow[t]{2}{*}{ Ireland } & $57.3(284)$ & $57.5(232)$ & $57.4(36)$ & $55.7(112)$ & $57.4(51)$ & $56.8(56)$ & $56.4(47)$ & $71.4(18)$ \\
\hline & [6.0] & [86.6] & {$[13.4]$} & {$[39.4]$} & {$[18.0]$} & [19.7] & {$[16.6]$} & {$[6.3]$} \\
\hline \multirow[t]{2}{*}{ Italy } & $64.3(274)$ & $63.6(223)$ & $66.7(38)$ & $62.2(44)$ & $62.3(77)$ & $66.7(85)$ & $63.6(44)$ & $65.5(24)$ \\
\hline & [5.4] & {$[85.4]$} & [14.6] & {$[16.1]$} & [28.1] & [31.0] & {$[16.1]$} & {$[8.8]$} \\
\hline \multirow[t]{2}{*}{ Netherlands } & $65.3(178)$ & $65.5(135)$ & $64.0(5)$ & $63.9(47)$ & $66.9(47)$ & $64.6(30)$ & $64.3(41)$ & $69.5(13)$ \\
\hline & {$[6.3]$} & {$[96.4]$} & [4.6] & {$[26.4]$} & [26.4] & [16.9] & {$[23.0]$} & {$[7.3]$} \\
\hline
\end{tabular}




\begin{tabular}{|c|c|c|c|c|c|c|c|c|}
\hline \multirow[t]{2}{*}{ Spain } & $64.8(77)$ & $64.8(69)$ & $63.5(6)$ & $61.3(16)$ & $66.9(21)$ & $63.8(17)$ & $63.8(16)$ & 70.7 (7) \\
\hline & {$[7.3]$} & {$[92.0]$} & {$[8.0]$} & [20.8] & {$[27.3]$} & [22.1] & [20.78] & [9.1] \\
\hline \multirow[t]{2}{*}{ Sweden } & $68.2(22)$ & $68.7(18)$ & $68.0(3)$ & $69.0(2)$ & $70.0(3)$ & $66.0(4)$ & $68.0(12)$ & $72.0(1)$ \\
\hline & [3.9] & {$[85.7]$} & [14.3] & {$[9.1]$} & [13.6] & [18.2] & [54.6] & [4.6] \\
\hline \multirow[t]{2}{*}{ Switzerland } & $65.1(140)$ & $64.0(85)$ & $70.1(18)$ & $62.0(39)$ & $63.6(24)$ & $69.1(42)$ & $64.8(32)$ & $64.3(3)$ \\
\hline & {$[4.7]$} & {$[82.5]$} & {$[17.5]$} & [27.9] & {$[17.1]$} & {$[30]$} & [22.86] & {$[2.1]$} \\
\hline \multirow[t]{2}{*}{ Australia } & 49.6 (189) & $50.0(86)$ & $52.0(7)$ & $48.5(63)$ & $49.3(72)$ & $52.7(14)$ & $50.7(32)$ & $52.8(8)$ \\
\hline & {$[3.8]$} & {$[92.5]$} & {$[7.5]$} & {$[33.3]$} & {$[38.1]$} & {$[7.4]$} & [16.9] & {$[4.2]$} \\
\hline \multirow[t]{2}{*}{ Canada } & $59.7(505)$ & $60.0(366)$ & $59.0(86)$ & $58.4(109)$ & $61.2(97)$ & $59.8(142)$ & $57.9(110)$ & $63.6(47)$ \\
\hline & {$[4.3]$} & {$[81.0]$} & {$[19.0]$} & {$[21.6]$} & {$[19.2]$} & {$[28.1]$} & {$[21.8]$} & {$[9.3]$} \\
\hline \multirow[t]{2}{*}{ United States } & $60.3(15861)$ & $60.3(13892)$ & 60.5 (1969) & $60.6(3944)$ & $57.0(4287)$ & $62.0(3405)$ & $58.3(2385)$ & $64.8(1840)$ \\
\hline & {$[5.5]$} & {$[87.6]$} & {$[12.4]$} & [24.9] & {$[27.0]$} & {$[21.5]$} & {$[15.0]$} & [11.6] \\
\hline \multirow[t]{2}{*}{ Europe } & 63.7 (4962) & $63.5(4001)$ & $65.0(485)$ & $61.9(1501)$ & $64.0(1184)$ & $64.6(1106)$ & $63.1(905)$ & $68.3(266)$ \\
\hline & [5.8] & [89.2] & {$[10.8]$} & [30.3] & [23.9] & [22.3] & {$[18.2]$} & [5.4] \\
\hline \multirow[t]{2}{*}{ New World } & $56.5(16555)$ & $56.8(14344)$ & $57.1(2062)$ & $55.8(4116)$ & $52.8(4456)$ & $58.1(3561)$ & $55.7(2527)$ & $60.4(1895)$ \\
\hline & {$[6.0]$} & {$[87.4]$} & {$[12.6]$} & [24.9] & [26.9] & {$[21.5]$} & {$[15.3]$} & [11.4] \\
\hline
\end{tabular}

Notes: Some observations did not specify the sex of workers. As a result, the total of identified men and female workers does not equal the number of observations. The breakdown of the sample in percentage is in square brackets. The standard deviation of the country totals is in italics.

Source: See text. 
TABLE 4

WORK HOURS: FIVE YEAR AVERAGES,1870-1889

(Number of observations)

[percentage]

\begin{tabular}{|c|c|c|c|c|c|c|}
\hline & $1870-74$ & $1875-79$ & $1880-84$ & 1884-89 & 1890-94 & 1895-99 \\
\hline $\begin{array}{l}\text { Belgium } \\
(172)\end{array}$ & $\begin{array}{c}66.0(2) \\
{[1.2]}\end{array}$ & $\begin{array}{c}72.0(1) \\
{[0.6]}\end{array}$ & $\begin{array}{c}69.2(64) \\
{[37.2]}\end{array}$ & $\begin{array}{c}69.9(35) \\
{[20.3]}\end{array}$ & $\begin{array}{c}65.7(57) \\
{[33.1]}\end{array}$ & $\begin{array}{c}63.3(13) \\
{[7.6]}\end{array}$ \\
\hline $\begin{array}{l}\text { Denmark } \\
(46)\end{array}$ & $\begin{array}{c}60.9(8) \\
{[17.4]}\end{array}$ & $\begin{array}{c}74.4(7) \\
{[15.2]}\end{array}$ & $\begin{array}{c}60.0(23) \\
{[0.5]}\end{array}$ & & $\begin{array}{c}60.0(1) \\
{[2.2]}\end{array}$ & $\begin{array}{c}57.7(7) \\
{[15.2]}\end{array}$ \\
\hline $\begin{array}{l}\text { France } \\
(650)\end{array}$ & $\begin{array}{c}64.2(32) \\
{[4.9]}\end{array}$ & $\begin{array}{c}60.0(19) \\
{[2.9]}\end{array}$ & $\begin{array}{c}65.7(73) \\
{[11.2]}\end{array}$ & $\begin{array}{c}69.5(29) \\
{[4.5]}\end{array}$ & $\begin{array}{c}65.4(307) \\
{[47.2]}\end{array}$ & $\begin{array}{c}64.4(190) \\
{[29.2]}\end{array}$ \\
\hline $\begin{array}{l}\text { Germany } \\
(672)\end{array}$ & $\begin{array}{c}66.8(175) \\
{[26.0]}\end{array}$ & $\begin{array}{c}65.0(33) \\
{[4.9]}\end{array}$ & $\begin{array}{c}63.4(238) \\
{[35.4]}\end{array}$ & $\begin{array}{c}64.9(177) \\
{[26.3]}\end{array}$ & $\begin{array}{c}64.4(24) \\
{[3.6]}\end{array}$ & $\begin{array}{c}59.1(25) \\
{[3.7]}\end{array}$ \\
\hline $\begin{array}{l}\text { Great } \\
\text { Britain } \\
(2447)\end{array}$ & $\begin{array}{c}56.6(444) \\
{[18.1]}\end{array}$ & $\begin{array}{c}54.2(421) \\
\quad[17.2]\end{array}$ & $\begin{array}{c}54.8(493) \\
{[20.1]}\end{array}$ & $\begin{array}{c}56.0(475) \\
{[19.4]}\end{array}$ & $\begin{array}{c}54.4(488) \\
{[19.9]}\end{array}$ & $\begin{array}{c}52.0(126) \\
{[5.1]}\end{array}$ \\
\hline $\begin{array}{l}\text { Ireland } \\
(284)\end{array}$ & $\begin{array}{c}59.1(46) \\
{[16.2]}\end{array}$ & $\begin{array}{c}55.9(12) \\
{[4.2]}\end{array}$ & $\begin{array}{c}58.3(51) \\
{[18.0]}\end{array}$ & $\begin{array}{c}59.1(61) \\
{[21.5]}\end{array}$ & $\begin{array}{c}55.8(88) \\
{[31.0]}\end{array}$ & $\begin{array}{c}53.9(26) \\
{[9.2]}\end{array}$ \\
\hline $\begin{array}{l}\text { Italy } \\
(274)\end{array}$ & $\begin{array}{c}64.7(45) \\
{[16.4]}\end{array}$ & $\begin{array}{c}62.7(13) \\
{[4.7]}\end{array}$ & $\begin{array}{c}63.8(66) \\
{[24.1]}\end{array}$ & $\begin{array}{c}64.9(56) \\
{[20.4]}\end{array}$ & $\begin{array}{c}64.3(94) \\
{[34.3]}\end{array}$ & \\
\hline $\begin{array}{l}\text { Netherlands } \\
(178)\end{array}$ & $\begin{array}{c}65.0(50) \\
{[28.1]}\end{array}$ & & $\begin{array}{c}64.4(43) \\
{[24.2]}\end{array}$ & $\begin{array}{c}64.3(42) \\
{[23.6]}\end{array}$ & $\begin{array}{c}67.7(43) \\
{[24.2]}\end{array}$ & \\
\hline $\begin{array}{l}\text { Spain } \\
(77)\end{array}$ & $\begin{array}{c}70.0(3) \\
{[3.9]}\end{array}$ & $\begin{array}{c}59.5(14) \\
{[18.2]}\end{array}$ & $\begin{array}{c}65.0(42) \\
{[54.5]}\end{array}$ & $\begin{array}{c}72.4(7) \\
{[9.1]}\end{array}$ & $\begin{array}{c}64.0(11) \\
{[14.3]}\end{array}$ & \\
\hline $\begin{array}{l}\text { Sweden } \\
(22)\end{array}$ & $\begin{array}{c}68.2(22) \\
{[100.0]}\end{array}$ & & & & & \\
\hline $\begin{array}{l}\text { Switzerland } \\
(140)\end{array}$ & $\begin{array}{c}69.6(39) \\
{[27.9]}\end{array}$ & $\begin{array}{c}60.0(3) \\
{[20.1]}\end{array}$ & $\begin{array}{c}64.8(56) \\
{[40.0]}\end{array}$ & $\begin{array}{c}61.1(8) \\
{[5.7]}\end{array}$ & $\begin{array}{c}62.1(26) \\
{[18.6]}\end{array}$ & $\begin{array}{c}60.1(8) \\
{[5.7]}\end{array}$ \\
\hline $\begin{array}{l}\text { Australia } \\
\text { (189) }\end{array}$ & & $\begin{array}{c}52.2(13) \\
{[6.9]}\end{array}$ & $\begin{array}{c}51.7(26) \\
{[13.8]}\end{array}$ & $\begin{array}{c}49.5(64) \\
{[33.9]}\end{array}$ & $\begin{array}{c}49.1(62) \\
{[32.8]}\end{array}$ & $\begin{array}{c}48.0(24) \\
{[12.7]}\end{array}$ \\
\hline $\begin{array}{l}\text { Canada } \\
(505)\end{array}$ & & $\begin{array}{c}59.2(12) \\
{[2.4]}\end{array}$ & $\begin{array}{c}59.8(115) \\
{[22.8]}\end{array}$ & $\begin{array}{c}59.0(269) \\
{[53.3]}\end{array}$ & $\begin{array}{c}63.3(42) \\
{[8.3]}\end{array}$ & $\begin{array}{c}60.1(67) \\
{[13.3]}\end{array}$ \\
\hline $\begin{array}{l}\text { United } \\
\text { States } \\
(15861)\end{array}$ & $\begin{array}{c}60.3(1562) \\
{[9.8]}\end{array}$ & $\begin{array}{c}60.3(2116) \\
{[13.3]}\end{array}$ & $\begin{array}{c}60.1(4672) \\
{[29.5]}\end{array}$ & $\begin{array}{c}60.0(2389) \\
{[15.1]}\end{array}$ & $\begin{array}{c}58.3(2136) \\
{[13.5]}\end{array}$ & $\begin{array}{c}55.9(2986) \\
{[18.8]}\end{array}$ \\
\hline $\begin{array}{l}\text { Old World } \\
\text { (4962) }\end{array}$ & $\begin{array}{c}64.7(866) \\
{[17.5]}\end{array}$ & $\begin{array}{c}64.6(523) \\
{[10.5]}\end{array}$ & $\begin{array}{c}63.0(1149) \\
{[23.2]}\end{array}$ & $\begin{array}{c}64.7(890) \\
{[17.9]}\end{array}$ & $\begin{array}{c}62.4(1139) \\
{[23.0]}\end{array}$ & $\begin{array}{c}58.7(395) \\
{[8.0]}\end{array}$ \\
\hline $\begin{array}{l}\text { New World } \\
(16555)\end{array}$ & $\begin{array}{c}60.3(1532) \\
{[9.3]}\end{array}$ & $\begin{array}{c}57.2(2141) \\
{[12.9]}\end{array}$ & $\begin{array}{c}57.2(4813) \\
{[29.1]}\end{array}$ & $\begin{array}{c}56.2(2722) \\
{[16.4]}\end{array}$ & $\begin{array}{c}56.9(2240) \\
{[13.5]}\end{array}$ & $\begin{array}{c}54.7(3077) \\
{[18.6]}\end{array}$ \\
\hline
\end{tabular}

Notes and source: See text. 
TABLE 5

ANNUAL WORKHOURS, 1870-1899 [s.d.]

\begin{tabular}{|c|c|c|c|c|c|c|c|c|}
\hline & \multirow{2}{*}{$\begin{array}{c}\text { Hours per } \\
\text { week }\end{array}$} & \multirow{2}{*}{ Days per year } & \multirow{2}{*}{ Days absent } & \multirow{2}{*}{$\begin{array}{l}\text { Weeks per } \\
\text { year }\end{array}$} & \multicolumn{4}{|c|}{ Annual hours } \\
\hline & & & & & 1890-1899 & 1870 & 1899 & 1998 \\
\hline Belgium & 67.7 & 292 & 5.5 & 47.8 & 3233 & 3295 & 3023 & 1568 \\
\hline Denmark & 62.0 & 300 & 5.3 & 49.1 & 3045 & 3291 & 2898 & 1664 \\
\hline France & 65.2 & 293 & 6.2 & 47.8 & 3117 & 3069 & 3083 & 1503 \\
\hline Germany & 65.4 & 295 & 8.4 & 47.8 & 3124 & 3191 & 2823 & 1523 \\
\hline Great Britain & 55.1 & 299 & 8.4 & 48.4 & 2669 & 2743 & 2519 & 1489 \\
\hline Ireland & 57.3 & 300 & 6.8 & 48.9 & 2800 & 2888 & 2634 & 1657 \\
\hline Italy & 64.3 & 290 & 5.5 & 47.4 & 3049 & 3068 & 3049 & 1506 \\
\hline Netherlands & 65.3 & 310 & 6.8 & 50.5 & 3300 & 3285 & 3421 & 1389 \\
\hline Spain & 64.8 & 282 & 6.8 & 45.9 & 2972 & 2981 & 2936 & 1908 \\
\hline Sweden & 68.2 & 300 & 5.9 & 49.0 & 3343 & 3343 & 3343 & 1582 \\
\hline Switzerland & 65.1 & 300 & 6.8 & 48.9 & 3181 & 3403 & 2956 & 1595 \\
\hline Australia & 49.6 & 305 & 6.8 & 49.7 & 2465 & 2592 & 2386 & 1641 \\
\hline Canada & 59.7 & 305 & 6.8 & 49.7 & 2697 & 2941 & 2992 & 1663 \\
\hline United States & 60.3 & 309 & 9.5 & 49.9 & 3010 & 3010 & 2795 & 1610 \\
\hline \multirow[t]{2}{*}{ Europe } & 63.7 & 296.5 & 6.6 & 48.3 & 3075.7 & 3141.5 & 2971.3 & 1580.4 \\
\hline & [4.1] & [7.2] & [1.1] & [1.2] & [204] & [209] & [266.3] & [134.3] \\
\hline \multirow[t]{2}{*}{ New World } & 56.5 & 306.3 & 7.7 & 49.8 & 2814.1 & 2847.5 & 2724.3 & 1638 \\
\hline & [6.0] & {$[2.3]$} & [1.6] & [0.1] & [303] & [224.1] & [309.3] & [21.7] \\
\hline
\end{tabular}

Notes and sources: Days absent from US Department of Labor, Twenty-Fourth Annual Report, and Workmen's Compensation Laws. Countries not identified were given the average of known values, 6.8 days. All other values from Table 3 and 4. 


\section{TABLE 6}

\section{ANNUAL WORKTIME AND GDP}

\begin{tabular}{lcccc}
\hline & \multicolumn{4}{c}{ Dependant variable: log annual hours } \\
\cline { 2 - 5 } & 1 & 2 & 3 & 4 \\
& All Countries & Old World & All countries & Old World \\
\hline Constant & 3415.65 & 3396.60 & 3473.10 & 3568.87 \\
GDP per capita & $(21.42)$ & $(20.42)$ & $(12.78)$ & $(12.56)$ \\
& -0.442 & -0.990 & -0.154 & -0.133 \\
Population & $(-2.63)$ & $(-1.67)$ & $(-2.18)$ & $-1.77)$ \\
& -0.003 & -0.005 & -0.002 & -0.005 \\
GDPgap & $(-0.88)$ & $(-1.70)$ & $(-0.81)$ & $-1.58)$ \\
& & & -0.021 & -0.006 \\
\hline $\mathrm{R}^{2}$ & & & $(-0.26)$ & $(-0.75)$ \\
$\mathrm{F}$ & 0.23 & 0.23 & 0.23 & 0.25 \\
$\mathrm{~N}$ & 3.77 & 2.90 & 2.43 & 2.08 \\
\hline
\end{tabular}

Notes: GDPgap is the difference in income per head from British levels. $t$ statistics in parentheses.

Sources: GDP per capita - Maddison, Monitoring; population - Mitchell, Historical Statistics. 
TABLE 7

\section{DETERMINANTS OF WORKING HOURS}

\begin{tabular}{|c|c|c|c|c|c|}
\hline & \multicolumn{5}{|c|}{ Dependent variable: log weekly hours } \\
\hline & 1 & 2 & 3 & 4 & 5 \\
\hline $\begin{array}{l}\text { GDP per } \\
\text { capita }\end{array}$ & $\begin{array}{c}-7.44 \mathrm{E}-05 \\
(-53.64)\end{array}$ & $\begin{array}{c}-7.09 \mathrm{E}-05 \\
(-47.69)\end{array}$ & $\begin{array}{l}-4.02 \mathrm{E}-05 \\
(-10.29)\end{array}$ & $\begin{array}{c}-6.65 \mathrm{E}-05 \\
(-47.05)\end{array}$ & $\begin{array}{c}-3.81 \mathrm{E}-05 \\
(-10.50)\end{array}$ \\
\hline Belgium & & & $\begin{array}{c}0.178 \\
(23.23)\end{array}$ & & $\begin{array}{c}0.171 \\
(23.71)\end{array}$ \\
\hline France & & & $\begin{array}{c}0.106 \\
(15.21)\end{array}$ & & $\begin{array}{c}0.101 \\
(15.46)\end{array}$ \\
\hline Germany & & & $\begin{array}{c}0.103 \\
(13.33)\end{array}$ & & $\begin{array}{c}0.098 \\
(13.46)\end{array}$ \\
\hline Ireland & & & $\begin{array}{l}-0.008 \\
(-1.21)\end{array}$ & & $\begin{array}{l}-.007 \\
(-0.93)\end{array}$ \\
\hline Italy & & & $\begin{array}{l}0.055 \\
(5.09)\end{array}$ & & $\begin{array}{l}0.047 \\
(4.64)\end{array}$ \\
\hline Netherlands & & & $\begin{array}{c}0.141 \\
(17.22)\end{array}$ & & $\begin{array}{c}0.134 \\
(17.57)\end{array}$ \\
\hline Scandinavia & & & $\begin{array}{l}0.083 \\
(6.30)\end{array}$ & & $\begin{array}{l}0.082 \\
(6.64)\end{array}$ \\
\hline Spain & & & $\begin{array}{l}0.070 \\
(5.23)\end{array}$ & & $\begin{array}{l}0.065 \\
(5.16)\end{array}$ \\
\hline Switzerland & & & $\begin{array}{c}0.127 \\
(13.27)\end{array}$ & & $\begin{array}{c}0.126 \\
(13.95)\end{array}$ \\
\hline Australia & & & $\begin{array}{l}-0.066 \\
(-6.95)\end{array}$ & & $\begin{array}{l}-0.067 \\
(-7.82)\end{array}$ \\
\hline Canada & & & $\begin{array}{l}0.008 \\
(1.00)\end{array}$ & & $\begin{array}{l}0.003 \\
(0.42)\end{array}$ \\
\hline United States & & & $\begin{array}{c}0.063 \\
(16.40)\end{array}$ & & $\begin{array}{c}0.039 \\
(14.85)\end{array}$ \\
\hline $\begin{array}{l}\text { Mining and } \\
\text { construction }\end{array}$ & & & & $\begin{array}{l}-0.025 \\
(-7.09)\end{array}$ & $\begin{array}{l}-0.022 \\
(-6.92)\end{array}$ \\
\hline Iron and steel & & & & $\begin{array}{l}0.032 \\
(9.03)\end{array}$ & $\begin{array}{l}0.030 \\
(9.48)\end{array}$ \\
\hline Textile & & & & $\begin{array}{c}0.042 \\
(10.41)\end{array}$ & $\begin{array}{c}0.040 \\
(11.12)\end{array}$ \\
\hline Service & & & & $\begin{array}{c}0.092 \\
(18.35)\end{array}$ & $\begin{array}{c}0.087 \\
(19.53)\end{array}$ \\
\hline $\mathrm{R}^{2}$ & 0.29 & 0.26 & 0.41 & 0.35 & 0.48 \\
\hline $\mathrm{F}$ & 2877.16 & 1175.85 & 329.97 & 581.79 & 342.20 \\
\hline $\mathrm{N}$ & 7225 & 6600 & 6600 & 6600 & 6600 \\
\hline
\end{tabular}

Notes: All regressions include a constant term and binary variable for sex of worker. The base case is a male worker in manufacturing in Great Britain. $t$ statistics in parentheses. 
TABLE 8

\section{DETERMINANTS OF WORKING HOURS BY COUNTRY}

\begin{tabular}{|c|c|c|c|c|c|c|}
\hline Country & GDP per capita & $\begin{array}{l}\text { Mining and } \\
\text { construction }\end{array}$ & Iron and steel & Textile & Service & $\mathrm{R}^{2}(\mathrm{~F})$ \\
\hline \multicolumn{7}{|l|}{ Old World } \\
\hline Belgium & $\begin{array}{c}-1.23 \mathrm{E}-04 \\
(-2.97)\end{array}$ & $\begin{array}{l}-0.036 \\
(1.58)\end{array}$ & $\begin{array}{l}0.054 \\
(2.39)\end{array}$ & $\begin{array}{l}0.093 \\
(3.87)\end{array}$ & $\begin{array}{l}0.064 \\
(2.04)\end{array}$ & $\begin{array}{c}0.17 \\
(5.31)\end{array}$ \\
\hline France & $\begin{array}{c}-4.14 \mathrm{E}-04 \\
(-2.49)\end{array}$ & $\begin{array}{l}-0.013 \\
(-1.28)\end{array}$ & $\begin{array}{l}0.031 \\
(3.01)\end{array}$ & $\begin{array}{l}0.060 \\
(5.78)\end{array}$ & $\begin{array}{l}0.108 \\
(7.74)\end{array}$ & $\begin{array}{c}0.18 \\
(21.15)\end{array}$ \\
\hline Germany & $\begin{array}{c}-8.87 \mathrm{E}-05 \\
(-4.43)\end{array}$ & $\begin{array}{l}-0.059 \\
(-3.81)\end{array}$ & $\begin{array}{l}-0.015 \\
(-0.90)\end{array}$ & $\begin{array}{l}0.009 \\
(0.41)\end{array}$ & $\begin{array}{l}0.033 \\
(1.86)\end{array}$ & $\begin{array}{c}0.09 \\
(8.65)\end{array}$ \\
\hline Great Britain & $\begin{array}{c}-3.23 \mathrm{E}-05 \\
(-4.23)\end{array}$ & $\begin{array}{l}-0.029 \\
(-5.94)\end{array}$ & $\begin{array}{l}0.033 \\
(6.35)\end{array}$ & $\begin{array}{l}0.020 \\
(3.20)\end{array}$ & $\begin{array}{l}0.094 \\
(9.83)\end{array}$ & $\begin{array}{c}0.15 \\
(69.14)\end{array}$ \\
\hline Italy & $\begin{array}{c}-4.30 \mathrm{E}-05 \\
(-0.46)\end{array}$ & $\begin{array}{c}-0.013 \\
(-0.794)\end{array}$ & $\begin{array}{l}0.001 \\
(0.09)\end{array}$ & $\begin{array}{l}0.049 \\
(3.14)\end{array}$ & $\begin{array}{l}0.027 \\
(1.33)\end{array}$ & $\begin{array}{c}0.11 \\
(5.19)\end{array}$ \\
\hline Ireland & $\begin{array}{c}-5.36 \mathrm{E}-05 \\
(-6.23)\end{array}$ & $\begin{array}{l}-0.020 \\
(-0.95)\end{array}$ & $\begin{array}{l}0.015 \\
(1.02)\end{array}$ & $\begin{array}{l}-0.015 \\
(-0.80)\end{array}$ & $\begin{array}{c}0.227 \\
(11.67)\end{array}$ & $\begin{array}{c}0.46 \\
(37.23)\end{array}$ \\
\hline Netherlands & $\begin{array}{c}-1.56 \mathrm{E}-05 \\
(-0.64)\end{array}$ & $\begin{array}{c}-0.001 \\
(-0.046)\end{array}$ & $\begin{array}{l}0.041 \\
(1.88)\end{array}$ & $\begin{array}{c}-0.016 \\
(-0.528)\end{array}$ & $\begin{array}{c}0.0843 \\
(2.70)\end{array}$ & $\begin{array}{c}0.10 \\
(2.45)\end{array}$ \\
\hline Switzerland & $\begin{array}{c}-1.37 \mathrm{E}-04 \\
(-7.92)\end{array}$ & $\begin{array}{l}-0.097 \\
(-1.80)\end{array}$ & $\begin{array}{l}-0.015 \\
(-1.38)\end{array}$ & $\begin{array}{l}0.043 \\
(3.09)\end{array}$ & $\begin{array}{c}-0.0037 \\
(-0.16)\end{array}$ & $\begin{array}{c}0.65 \\
(30.43)\end{array}$ \\
\hline \multicolumn{7}{|l|}{ New World } \\
\hline Canada & $\begin{array}{c}1.039 \mathrm{E}-04 \\
(3.71)\end{array}$ & $\begin{array}{l}0.007 \\
(0.65)\end{array}$ & $\begin{array}{l}0.053 \\
(5.23)\end{array}$ & $\begin{array}{c}0.0871 \\
(4.04)\end{array}$ & $\begin{array}{l}0.086 \\
(6.82)\end{array}$ & $\begin{array}{c}0.16 \\
(14.56)\end{array}$ \\
\hline United States & $\begin{array}{c}-3.325 \mathrm{E}-05 \\
(-6.29)\end{array}$ & $\begin{array}{l}-0.001 \\
(-1.49)\end{array}$ & $\begin{array}{l}0.050 \\
(7.69)\end{array}$ & $\begin{array}{l}0.0794 \\
(10.66)\end{array}$ & $\begin{array}{c}0.106 \\
(13.43)\end{array}$ & $\begin{array}{c}0.22 \\
(72.91)\end{array}$ \\
\hline
\end{tabular}

Notes: Dependent variable is weekly working hours. The base case is a male worker in manufacturing. All regressions include a constant term and binary variable for sex of worker. $t$ statistics in parentheses. 
TABLE 9

\section{DETERMINANTS OF WORKING HOURS BY SECTOR}

\begin{tabular}{|c|c|c|}
\hline \multicolumn{3}{|c|}{ Dependent variable: log weekly hours } \\
\hline & Textile & Mining and construction \\
\hline Constant & $\begin{array}{c}4.114 \\
(84.47)\end{array}$ & $\begin{array}{c}4.088 \\
(108.49)\end{array}$ \\
\hline GDP per capita & $\begin{array}{c}-1.777 \mathrm{E}-05 \\
(-1.28)\end{array}$ & $\begin{array}{c}-2.593 \mathrm{E}-05 \\
(-2.40)\end{array}$ \\
\hline Time & $\begin{array}{l}-0.002 \\
(-1.95)\end{array}$ & $\begin{array}{l}0.001 \\
(1.38)\end{array}$ \\
\hline GDP*Time & $\begin{array}{c}6.798 \mathrm{E}-08 \\
(0.219)\end{array}$ & $\begin{array}{c}-6.648 \mathrm{E}-07 \\
(-2.34)\end{array}$ \\
\hline Belgium & $\begin{array}{c}0.220 \\
(15.07)\end{array}$ & $\begin{array}{c}0.198 \\
(13.62)\end{array}$ \\
\hline France & $\begin{array}{l}0.166 \\
(5.25)\end{array}$ & $\begin{array}{l}0.110 \\
(5.70)\end{array}$ \\
\hline Germany & $\begin{array}{l}0.131 \\
(5.83)\end{array}$ & $\begin{array}{l}0.105 \\
(5.82)\end{array}$ \\
\hline Ireland & $\begin{array}{l}-0.008 \\
(-0.42)\end{array}$ & $\begin{array}{c}0.011 \\
(0.724)\end{array}$ \\
\hline Italy & $\begin{array}{l}0.134 \\
(4.14)\end{array}$ & $\begin{array}{c}0.0724 \\
(2.58)\end{array}$ \\
\hline Netherlands & $\begin{array}{l}0.121 \\
(6.78)\end{array}$ & $\begin{array}{c}0.158 \\
(10.94)\end{array}$ \\
\hline Scandinavia & $\begin{array}{l}0.108 \\
(3.31)\end{array}$ & $\begin{array}{l}0.110 \\
(3.98)\end{array}$ \\
\hline Spain & $\begin{array}{l}0.099 \\
(2.94)\end{array}$ & $\begin{array}{l}0.058 \\
(2.09)\end{array}$ \\
\hline Switzerland & $\begin{array}{c}0.184 \\
(10.56)\end{array}$ & $\begin{array}{l}0.136 \\
(7.68)\end{array}$ \\
\hline Australia & $\begin{array}{l}-0.034 \\
(-1.42)\end{array}$ & $\begin{array}{l}-0.057 \\
(-4.07)\end{array}$ \\
\hline Canada & $\begin{array}{l}0.042 \\
(1.60)\end{array}$ & $\begin{array}{l}0.034 \\
(1.51)\end{array}$ \\
\hline United States & $\begin{array}{l}0.101 \\
(9.23)\end{array}$ & $\begin{array}{l}0.056 \\
(6.21)\end{array}$ \\
\hline $\mathrm{R}^{2}$ & 0.59 & 0.52 \\
\hline $\mathrm{F}$ & 125.84 & 125.54 \\
\hline $\mathrm{N}$ & 1396 & 1854 \\
\hline
\end{tabular}

Notes: All regressions include a binary variable for sex of worker. $\mathrm{t}$ statistics in parentheses. 
TABLE 10

ANNUAL HOURS BY COUNTRY AND BY DECADE: TEXTILES

(Number of observations)

\begin{tabular}{|c|c|c|c|}
\hline & $1870-79$ & $1880-89$ & $1890-99$ \\
\hline \multirow[t]{2}{*}{ Belgium } & & $73.1(30)$ & $68.1(25)$ \\
\hline & & {$[1.3]$} & {$[2.1]$} \\
\hline Denmark & $67.0(1)$ & $60.0(1)$ & $63.0(1)$ \\
\hline \multirow[t]{2}{*}{ France } & $64.7(18)$ & $71.3(31)$ & $65.4(148)$ \\
\hline & [2.9] & [0.9] & [1.9] \\
\hline \multirow[t]{2}{*}{ Germany } & $65.8(39)$ & $66.8(97)$ & $60.0(6)$ \\
\hline & {$[2.5]$} & [4.2] & - \\
\hline \multirow[t]{2}{*}{ Great Britain } & $57.0(181)$ & $55.9(231)$ & $54.3(63)$ \\
\hline & {$[2.5]$} & {$[1.4]$} & [1.4] \\
\hline \multirow[t]{2}{*}{ Italy } & $68.2(22)$ & $66.7(37)$ & $64.7(26)$ \\
\hline & {$[8.8]$} & {$[4.7]$} & [3.9] \\
\hline \multirow[t]{2}{*}{ Ireland } & $58.6(14)$ & $56.4(31)$ & $54.4(11)$ \\
\hline & {$[2.1]$} & {$[0.8]$} & {$[1.0]$} \\
\hline \multirow[t]{2}{*}{ Netherlands } & $64.7(4)$ & $64.5(14)$ & $63.5(12)$ \\
\hline & {$[6.6]$} & {$[2.1]$} & {$[1.5]$} \\
\hline Spain & 60.0 & $64.1(10)$ & $64.0(6)$ \\
\hline Sweden & $66.0(4)$ & & \\
\hline \multirow[t]{2}{*}{ Switzerland } & $72.0(24)$ & $65.6(12)$ & $65.0(6)$ \\
\hline & & {$[0.5]$} & \\
\hline \multirow[t]{2}{*}{ Australia } & $48.0(1)$ & $52.5(8)$ & $48.8(5)$ \\
\hline & & {$[5.7]$} & [1.1] \\
\hline \multirow[t]{2}{*}{ Canada } & $59.0(1)$ & $59.7(129)$ & $59.8(12)$ \\
\hline & & {$[0.4]$} & \\
\hline \multirow[t]{2}{*}{ United States } & $62.3(633)$ & $62.9(1673)$ & $60.9(1065)$ \\
\hline & {$[0.8]$} & [1.7] & {$[1.3]$} \\
\hline \multirow[t]{2}{*}{ Europe } & $64.4(308)$ & $64.4(494)$ & $62.3(304)$ \\
\hline & {$[4.6]$} & [5.7] & [4.6] \\
\hline \multirow[t]{2}{*}{ New World } & $57.1(635)$ & $58.4(1810)$ & $56.5(1082)$ \\
\hline & [8.3] & {$[5.3]$} & [6.7] \\
\hline \multirow[t]{2}{*}{ All } & $60.8(943)$ & $61.4(2304)$ & $59.4(1386)$ \\
\hline & {$[5.2]$} & {$[4.3]$} & {$[4.1]$} \\
\hline
\end{tabular}




\section{TABLE 11}

\section{RAW COTTON CONSUMPTION PER CAPITA, 1870-1899}

(tons per 1000 inhabitants)

[s.d]

\begin{tabular}{lccc}
\hline & $\mathbf{1 8 7 0 - 7 9}$ & $\mathbf{1 8 8 0 - 8 9}$ & $\mathbf{1 8 9 0 - 9 9}$ \\
\hline Belgium & 4.25 & 4.04 & 5.34 \\
France & 2.29 & 2.85 & 4.11 \\
Germany & 2.80 & 2.39 & 5.19 \\
Italy & 0.91 & 2.39 & 3.44 \\
Netherlands & 2.48 & 2.97 & 3.13 \\
Spain & 2.02 & 2.79 & 3.62 \\
Sweden & 1.89 & 2.39 & 3.16 \\
Switzerland & 11.88 & 8.68 & 8.42 \\
United Kingdom & 24.11 & 25.48 & 25.60 \\
\hline Europe & $5.85[7.6]$ & $6.00[7.6]$ & $6.89[7.2]$ \\
\hline
\end{tabular}

Source: Population and raw cotton consumption - Mitchell, Historical Statistics. 
TABLE 12

DETERMINANTS OF COMPARATIVE ADVANTAGE IN TEXTILES

\begin{tabular}{lccc}
\hline & \multicolumn{3}{c}{ Dependant variable: consumption (per capita) of cotton } \\
\cline { 2 - 4 } & 1 & 2 & 3 \\
\hline Constant & -0.997 & -6.809 & -4.355 \\
& $(-5.80)$ & $(-15.67)$ & $(-9.49)$ \\
Log illiteracy & 0.093 & 0.095 & -0.192 \\
& $(6.64)$ & $(7.37)$ & $(-1.24)$ \\
Log labor-land & 0.056 & 0.133 & 0.160 \\
& $(5.27)$ & $(11.95)$ & $(14.90)$ \\
Log hours & & 1.115 & 0.540 \\
& & $(14.35)$ & $(6.15)$ \\
Legislation & & & -0.263 \\
& & & $(-11.72)$ \\
\hline $\mathrm{R}^{2}$ & & & 0.31 \\
$\mathrm{~F}$ & & 9.22 & 118.46 \\
$\mathrm{~N}$ & 38.19 & 1042 & 1042 \\
\hline
\end{tabular}

Note: Labor in labor-land is population squared. Legislation is a binary variable equal to one if minimal restrictions on worktime enacted. Countries and dates - Britain and Switzerland, from 1870; Germany and France, from 1890. Countries dummies included but not reported. $t$ statistics in parentheses.

Sources: Illiteracy and land - Foreman-Peck and Lains, "European Economic Development"; labor - Mitchell, Historical Statistics; legislation - Huberman and Lewchuk, "European Economic Integration." 
TABLE A1

OCCUPATIONS BY CATEGORY

\begin{tabular}{lllll}
\hline \multicolumn{1}{c}{$\begin{array}{c}\text { Mining and } \\
\text { construction }\end{array}$} & \multicolumn{1}{c}{$\begin{array}{c}\text { Iron and } \\
\text { steel }\end{array}$} & \multicolumn{1}{c}{ Textile } & Manufacturing & Service \\
\hline Bricklayers & Blacksmiths & Carders & Cabinet makers & Bakers \\
Carpenters, joiners & Boiler makers & Dyers & Cigar makers & Bookkeepers \\
Masons & Engineers, & Pattern makers & Compositers & Clerks \\
Miners, coal & locomotive & Reeelers & Coopers & Teamsters \\
Painters & Engineers, & Spinners, cotton & Harness and & Watchmen \\
Plasterers & stationary & Spinners, wool & saddlemakers & \\
Plumbers & Firemen, & Spoolers & Hod carriers & \\
Sawyers, lumber & locomotive & Twisters & Shoemakers & \\
Stonecutters & Firemen, & Warpers & Tailors & \\
& stationary & Weavers, cotton & Upholsterers & \\
& Machinists & Weavers, woolen & Watchamakers & \\
& Molders, iron & Winders & & \\
& Tinsmiths & & & \\
& Tuners, metal & & & \\
& & & & \\
\end{tabular}




\section{TABLE A2}

\section{WORK HOURS IN THE UNITED STATES}

(Number of observations)

[percentages]

$$
\text { [s.d.] }
$$

\begin{tabular}{|c|c|c|c|c|c|c|}
\hline \multicolumn{7}{|c|}{ Hours of work per week } \\
\hline & All & $\begin{array}{l}\text { Mining and } \\
\text { construction }\end{array}$ & Iron and steel & Textile & Manufacturing & Services \\
\hline \multirow[t]{2}{*}{ New England } & $61.8(3594)$ & $58.6(535)$ & $61.4(903)$ & $62.7(1,427)$ & $58.3(277)$ & $65.3(452)$ \\
\hline & {$[5.5]$} & [14.9] & {$[25.1]$} & {$[39.7]$} & [7.7] & {$[12.6]$} \\
\hline \multirow[t]{2}{*}{ Middle Atlantic } & $59.6(4109)$ & $56.8(1099)$ & $60.6(1088)$ & $60.7(831)$ & $58.2(589)$ & $63.1(502)$ \\
\hline & [4.9] & {$[26.7]$} & {$[26.5]$} & [20.2] & {$[14.3]$} & {$[12.2]$} \\
\hline \multirow[t]{2}{*}{ East North Central } & $59.5(2739)$ & $56.9(751)$ & $60.6(817)$ & $60.4(282)$ & $58.0(532)$ & $64.0(357)$ \\
\hline & [5.7] & {$[27.4]$} & {$[29.8]$} & [6.9] & [19.4] & {$[13.0]$} \\
\hline \multirow{2}{*}{$\begin{array}{l}\text { West North } \\
\text { Central }\end{array}$} & $58.9(1703)$ & $56.9(530)$ & $59.9(464)$ & $59.5(125)$ & $58.4(395)$ & $62.8(189)$ \\
\hline & {$[5.3]$} & {$[31.1]$} & {$[27.2]$} & {$[7.3]$} & {$[23.2]$} & {$[11.1]$} \\
\hline \multirow[t]{2}{*}{ South Atlantic } & $66.6(2322)$ & $58.2(582)$ & $61.9(644)$ & $65.9(531)$ & $58.2(343)$ & $65.0(222)$ \\
\hline & [5.8] & {$[25.1]$} & {$[27.1]$} & [22.9] & {$[14.8]$} & [9.6] \\
\hline \multirow[t]{2}{*}{ South Central } & $61.3(710)$ & $57.8(189)$ & $62.0(194)$ & $64.1(158)$ & $58.8(111)$ & $68.0(58)$ \\
\hline & {$[5.1]$} & {$[26.6]$} & {$[27.3]$} & {$[22.3]$} & {$[15.6]$} & {$[8.2]$} \\
\hline \multirow[t]{2}{*}{ West } & $56.9(684)$ & $53.9(258)$ & $57.4(177)$ & $60.3(51)$ & $57.0(138)$ & $65.5(60)$ \\
\hline & {$[5.8]$} & [37.7] & [25.9] & [7.5] & [20.2] & [8.8] \\
\hline \multirow[t]{2}{*}{ United States } & $60.7(15861)$ & $57.0(3944)$ & $60.5(4287)$ & $62.0(3405)$ & $58.2(2385)$ & $64.8(1840)$ \\
\hline & {$[5.5]$} & [24.9] & [27.0] & [21.5] & {$[15.0]$} & [11.6] \\
\hline
\end{tabular}


TABLE A3

GDP PER WORKER HOUR: MADDISON AND REVISED ESTIMATES

[s.d.]

\begin{tabular}{|c|c|c|c|c|c|c|}
\hline & \multicolumn{3}{|c|}{ Maddison } & \multicolumn{3}{|c|}{ New } \\
\hline & 1870 & 1900 & 1913 & 1870 & 1900 & 1913 \\
\hline Belgium & 2.17 & 3.02 & 3.68 & 1.95 & 2.70 & 3.32 \\
\hline Denmark & 1.57 & 2.34 & 3.58 & 1.40 & 2.18 & 3.38 \\
\hline France & 1.38 & 2.28 & 2.88 & 1.32 & 1.98 & 2.43 \\
\hline Germany & 1.55 & 2.30 & 3.03 & 1.38 & 2.15 & 2.50 \\
\hline Italy & 1.05 & 1.35 & 2.13 & 0.99 & 1.17 & 1.78 \\
\hline Netherlands & 2.43 & 3.28 & 4.11 & 2.19 & 2.60 & 3.35 \\
\hline Spain & 1.22 & 1.40 & 2.00 & 1.21 & 1.43 & 2.06 \\
\hline Sweden & 1.22 & 2.03 & 2.58 & 1.08 & 1.63 & 2.00 \\
\hline Switzerland & 1.53 & 2.49 & 3.30 & 1.34 & 2.29 & 3.18 \\
\hline $\begin{array}{l}\text { United } \\
\text { Kingdom }\end{array}$ & 2.55 & 3.63 & 4.31 & 2.78 & 3.92 & 4.69 \\
\hline Australia & 3.48 & 3.69 & 5.48 & 3.77 & 4.35 & 5.99 \\
\hline Canada & 1.71 & 2.23 & 4.45 & 1.63 & 2.02 & 3.78 \\
\hline $\begin{array}{l}\text { United } \\
\text { States }\end{array}$ & 2.25 & 3.66 & 5.12 & 2.22 & 3.54 & 4.95 \\
\hline Old World & $\begin{array}{c}1.67 \\
{[0.5]}\end{array}$ & $\begin{array}{l}2.41 \\
{[0.7]}\end{array}$ & $\begin{array}{l}3.16 \\
{[0.8]}\end{array}$ & $\begin{array}{c}1.56 \\
{[0.6]}\end{array}$ & $\begin{array}{l}2.21 \\
{[0.8]}\end{array}$ & $\begin{array}{l}2.87 \\
{[0.9]}\end{array}$ \\
\hline New World & $\begin{array}{c}2.48 \\
{[0.9]}\end{array}$ & $\begin{array}{c}3.19 \\
{[0.8]}\end{array}$ & $\begin{array}{c}5.02 \\
{[0.5]}\end{array}$ & $\begin{array}{l}2.54 \\
{[1.1]}\end{array}$ & $\begin{array}{l}3.30 \\
{[1.2]}\end{array}$ & $\begin{array}{l}4.91 \\
{[1.1]}\end{array}$ \\
\hline All & 2.48 & $\begin{array}{l}2.80 \\
{[0.6]}\end{array}$ & $\begin{array}{l}4.09 \\
{[1.4]}\end{array}$ & $\begin{array}{l}2.05 \\
{[0.7]}\end{array}$ & $\begin{array}{l}2.75 \\
{[0.8]}\end{array}$ & $\begin{array}{l}3.89 \\
{[1.4]}\end{array}$ \\
\hline
\end{tabular}


TABLE A4

GDP ADJUSTED FOR LEISURE

[s.d.]

\begin{tabular}{|c|c|c|c|c|c|}
\hline & \multicolumn{2}{|c|}{ Work hours per person } & \multicolumn{3}{|c|}{ GDP per capita } \\
\hline & 1870 & 1899 & 1870 & 1899 & $\begin{array}{c}\text { Leisure } \\
\text { adjusted }\end{array}$ \\
\hline Belgium & 1450.7 & 1330.9 & 2640 & 3579 & 3806 \\
\hline Denmark & 1389.8 & 1223.9 & 2008 & 2840 & 3093 \\
\hline France & 1433.6 & 1440.3 & 2059 & 2884 & 2875 \\
\hline Germany & 1488.0 & 1316.5 & 1913 & 3049 & 3307 \\
\hline Italy & 1452.9 & 1443.9 & 1467 & 1663 & 1670 \\
\hline Netherlands & 1250.2 & 1302.1 & 2640 & 3703 & 3609 \\
\hline Spain & 1132.9 & 1115.5 & 1376 & 2040 & 2057 \\
\hline Sweden & 1547.5 & 1547.4 & 1664 & 2491 & 2491 \\
\hline Switzerland & 1676.9 & 1456.8 & 2172 & 3463 & 3816 \\
\hline $\begin{array}{l}\text { United } \\
\text { Kingdom }\end{array}$ & 1195.0 & 1097.0 & 3263 & 4670 & 4939 \\
\hline Australia & 1005.7 & 925.7 & 3801 & 4113 & 4357 \\
\hline Canada & 1128.9 & 1148.5 & 1620 & 2649 & 2621 \\
\hline United States & 1197.1 & 1111.7 & 2457 & 4056 & 4268 \\
\hline Old World & $\begin{array}{l}1401.75 \\
{[166.2]}\end{array}$ & $\begin{array}{l}1327.43 \\
{[149.4]}\end{array}$ & $\begin{array}{l}2120.20 \\
{[586.6]}\end{array}$ & $\begin{array}{l}3038.20 \\
{[871.0]}\end{array}$ & $\begin{array}{l}3166.30 \\
{[954.8]}\end{array}$ \\
\hline New World & $\begin{array}{c}1110.57 \\
\text { [97.0] }\end{array}$ & $\begin{array}{l}1061.97 \\
{[119.4]}\end{array}$ & $\begin{array}{l}2626.00 \\
{[1100.3]}\end{array}$ & $\begin{array}{l}3606.00 \\
{[829.3]}\end{array}$ & $\begin{array}{l}3748.67 \\
{[977.6]}\end{array}$ \\
\hline All & $\begin{array}{l}1256.16 \\
{[205.9]}\end{array}$ & $\begin{array}{l}1194.70 \\
{[187.7]}\end{array}$ & $\begin{array}{l}2373.10 \\
{[357.7]}\end{array}$ & $\begin{array}{l}3322.10 \\
{[401.5]}\end{array}$ & $\begin{array}{l}6457.48 \\
{[411.8]}\end{array}$ \\
\hline
\end{tabular}

Sources: Employment and GDP per capita - Maddison, Monitoring; work hours - Table 5. 


\section{FIGURE 1}

\section{GDP AND ANNUAL WORK HOURS}

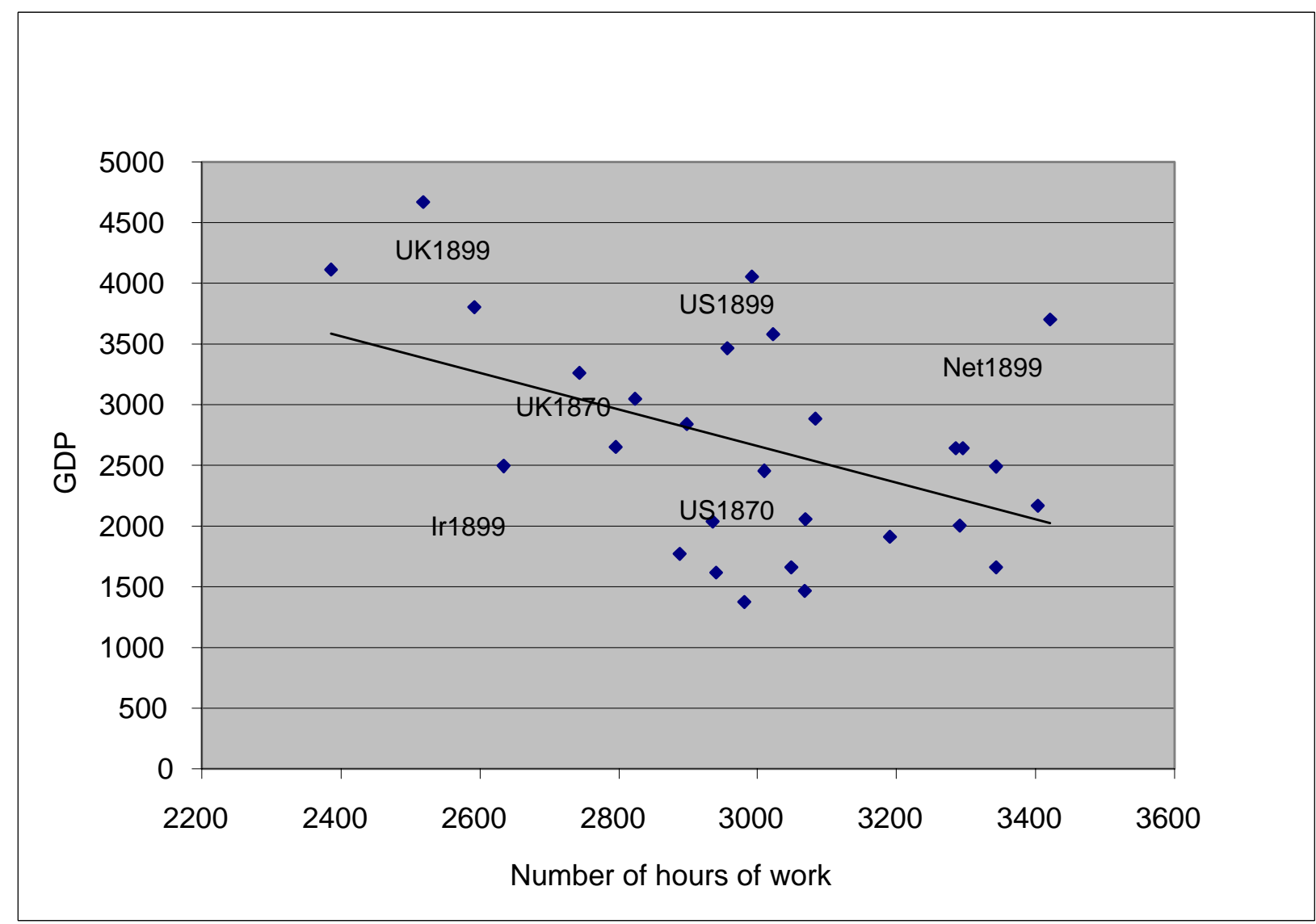

Note: The line represents the regression of annual work hours $=3363-0.137$ GDP per capita. The relevant $\mathrm{t}$ statistic is $-2.604 ; \mathrm{R}^{2}=.21 ; \mathrm{F}=6.783(\mathrm{p}=.015)$

Sources: GDP per capita - Maddison, Monitoring; work hours - Table 5. 


\section{REFERENCES}

Altman, Morris. "New Estimates of Hours of Work and Real Income in Canada from the 1880s to 1930: Long-Run Trends and Workers' Preferences," Review of Income and Wealth 45, no. 3 (September 1999): 353-72.

Atack, Jeremy and Fred Bateman. "How Long Was the Workday in 1880?" Journal of Economic History 52, no. 1 (1992):129-60.

Atack, Jeremy, Fred Bateman, and Robert A. Margo. "Productivity in Manufacturing and the Length of the Working Day: Evidence from the 1880 Census of Manufactures." Department of Economics, Vanderbilt University, working paper, no. 00-W45, 2000.

Beckerman, W. "Comparative Growth Rates of 'Measurable Economic Welfare': Some Experimental Calculations." Economic Growth and Resources, Vol. 2, edited by R. C. O. Matthews. New York: St. Martin's Press, 1980.

Bell, Linda and Richard B. Freeman. "Why Do Americans and Germans Work Different Hours?" National Bureau of Economic Research, working paper, no. 4808, 1995.

Bienefeld, M. A. Working Hours in British Industry. London: Weidenfeld and Nicolson, 1972.

Bruland, Kristina. "The European Textile Industry in the 1870s: Through British Eyes." Unpublished mimeo, Department of History, University of Oslo, 1998.

Christensen, J. P. Lønudviklingen inden for dansk håndværk og industri, 1870-1914. Copenhagen: Akademisk Förlag, 1975.

Clark, Gregory. “Why Isn't the Whole World Developed? Lessons from the Cotton Mills.” Journal of Economic History 47, no. 1 (March 1987): 1134-67.

. "Factory Discipline.” Journal of Economic History 54, no. 1 (March 1994): 128-64.

Clark, Gregory, Michael Huberman, and Peter H. Lindert. "A British Food Puzzle, 1770-1850." Economic History Review 48, no. 2 (May 1995): 215-37.

Costa, Dora L. "The Wage and the Length of the Workday: From the 1890s to 1991." Journal of Labour Economics 18, no. 1 (2000): 156-91.

Crafts, N. F. R. "The Human Development Index and Changes in Standards of Living: Some Historical Comparisons." European Review of Economic History 1, no. 2 (1997): 299-322.

Cross, Gary. A Quest for Time: The Reduction of Work in Britain and France, 1840-1940. Berkeley: University of California Press, 1989.

Decouflé, A.-C. and N. Svendsen. "Contribution à une histoire des durées du travail dans l'industrie française du milieu du XIXe siècle à la seconde guerre mondiale.” Travail et emploi 20 (1984): 57-71. 
de Vries, Jan. "The Industrial Revolution and the Industrious Revolution.” Journal of Economic History 54, no. 2 (June 1994): 249-70.

Ehrenberg, Ronald. G. Labor Markets and Integrating National Economies. Washington: Brookings Institution, 1994.

Farnie, Douglas A. The English Cotton Industry and the World Market, 1815-1896. Oxford: Calrendon Press, 1979.

Federico, Giovanni. L'Industria mondiale della seta dalla Restaurazione alla grande crisi. Venice: Marsilio, 1994

Follows, John W. Antcedents of the Internatonal Labour Organization. Oxford: Clarendon Press, 1951.

Foreman-Peck, James and Pedro Lains. "European Economic Development: The Core and the Southern Periphery, 1870-1910." In The Mediterranean Response to Globalization before 1950, edited by S. Pamuk and Jefrey G. Williamson. London: Routledge, 2000.

Gårdlund, Torsten. Industrialismens Sämhalle. Stockholm: Tidens Förlag, 1955.

Heikinnen, Sakari. Labour and the Market: Workers, Wages and Living Standards in Finland, 1850-1913. Helsinki, Commentationes Scientiarum Socialium, 1997.

Hoffmann, Walter. Das Wachstum der deutschen Wirtschaft seit der Mitte des 19. Jahrhunderts. Berlin: Springer Verlag, 1965.

Huberman, Michael. Escape from the Market: Negotiating Work in Lancashire. Cambridge: Cambridge University Press, 1996.

Huberman, Michael and Wayne Lewchuk. "European Economic Integration and the Labour Compact, 1850-1913." European Review of Economic History, forthcoming

Kaplow, Jeffrey. "La fin de la Saint-Lundi: Étude sur le Paris ouvrier au XIXe siècle.” Temps Libre, 2 (1981), 22-38.

Maddison, Angus. Economic Growth in the West. New York: Twentieth Century Fund, 1964.

. Phases of Capitalist Development. New York: Oxford University Press, 1982.

. "Growth and Slowdown in Advanced Capitalist Economies." Journal of Economic Literature 25 (1987): 649-98.

- Monitoring the World Economy, 1820-1992. Paris: Organization for Economic Cooperation and Development, 1995.

The World Economy: A Millennial Perspective. Paris: Organization for Economic Cooperation and Development, 2001.

Marchand, Olivier and Claude Thélot. Deux siècles de travail en France. Paris: INSEE, 1991. 
Matthews, R. C. O., C. H. Feinstein, and J. C. Odling-Smee. British Economic Growth, 1856-1973. Stanford: Stanford University Press, 1982.

Mitchell, Brian R. European Historical Statistics, 1750-1975. Second edition. New York: Facts on File, 1980 .

O'Rourke, Kevin H. and Jeffrey G. Williamson. Globalization and History: The Evolution of a Nineteenth-Century Atlantic Economy. Cambridge: MIT Press, 1999.

$\overline{23-50 .}$

. "When did Globalization Begin?” European Review of Economic History 6, no. 1 (April 2002):

Pollard, Sidney. The Industrialization of Europe, 1760-1970. London: Oxford University Press, 1981.

. "Labour in Great Britain." In The Cambridge Ecoonomic History of Europe, vol II, part 2,

edited by Peter Mathias and M. M. Postan. New York: Cambridge University Press, 1978.

Phelps Brown, E. H., and M. H. Browne. "Hours of Work." In The International Encyclopedia of the Social Sciences, vol. 8, pp. 487-90. New York: Colliers, 1972.

Rees, Albert. The Economics of Work and Pay. New York: Harper \& Row, 1973.

Rist, Charles. La réglementation légale de la journée de travail de l'ouvrier adulte. Paris: Larose, 1898.

Rodrik, Dani. "Labor Standards in International Trade: Do They Matter and What Do We Know About Them." In Emerging Agenda for Global Trade: High States for Developing Countries, edited by Robert Z. Lawrence, Dani Rodrik and John Walley. Washington, D. C.: Johns Hopkins University Press, 1996.

Rosenband, Leonard N. Papermaking in Eighteenth-Century France: Management, Labor, and Revolution at the Montgolfieer Mill, 1761-1805. Baltimore: Johns Hopkins, 2000.

Rosenbloom, Joshua L. "One Market or Many? Labor Market Integration in the Late Nineteenth Century United States." Journal of Economic History 50, no. 1 (March 1990): 85-109.

$\overline{241-68 .}$

"Male Labor Supply in the Late Nineteenth Century." Research in Economic History 14 (1993):

. "Was There a National Labor Market at the End of the Nineteenth Century? New Evidence on Earnings in Manufacturing." Journal of Economic History 56, no. 3 (September 1996): 626-56.

Scholliers, Peter. Wages, Manufacturers and Workers in the Nineteenth Century Factory: The Voortman Cotton Mill in Ghent. Oxford: Berg, 1996.

Sheills, Martha E. "Collective Choice of Working Conditions: Hours in Britain and US Steel, 18901923." Journal of Economic History 55, no. 2 (June 1990): 379-92.

Tegle, Stig. "Den Ordinarie Veckoarsbetstiden i Sverige, 1860-1980: En översikt." Unpublished mimeo, University of Lund, 1982. 
United Kingdom. Parliamentary Papers (PP). 1870. Reports from Her Majesty's Diplomatic and Consular Agents, vol. LXVI.

. PP. 1871. Reports from Her Majesty's Diplomatic and Consular Agents, vol. LXVIII.

. PP. 1872. Reports from Her Majesty's Diplomatic and Consular Agents, vol. LXII.

. PP. 1893-94. Commission on Labour, Foreign Reports, vol XXXIX.

. PP. 1899. First Annual Abstract of Foreign Labour Statistics, vol. XCII.

. PP. 1901. Second Annual Abstract of Foreign Labour Statistics, vol. LXXIII.

. PP. 1905. International Conference on Labour, vol. LXXIII.

. PP. 1906. Third Annual Abstract of Foreign Labour Statistics, vol. CXIII.

United States, Department of Labor. Fifteenth Annual Report of the Commissioner of Labor: Wages in Commercial Countries. Washington, 1900.

- 24th Annual Report of the Commissioner of Labor for 1909. Workmen's Insurance and Compensation Systems in Europe. Washington, 1911.

- Workmen's Compensation Laws of the United States and Foreign Countries. Bulletin of the United States Bureau of Labor Statistics, Department of Labor, no. 126, 1914.

Voth, Hans-Joachim. "Time and Work in Eighteenth Century London." Journal of Economic History 58, no. 1 (March 1998): pp. 29-58. Time and Work in England, 1750-1830. Oxford: Clarendon Press, 2000.

Williamson, Jeffrey G. “The Evolution of Global Labor Markets since 1830: Background Evidence and Hypotheses." Explorations in Economic History 32, no. 1 (1995): 141-96.

Wintle, Michael. An Economic and Social History of the Netherlands 1800-1920: Demographic, Economic and Social Transition. Cambridge: Cambridge University Press.

Van Zanden, J. L. "Indusrialization in the Netherlands." In The Industrial Revolution in National Context: Europe and the USA, edited by Mikulas Teich and Roy Porter. Cambridge: Cambridge University Press.

Zamagni, Vera. The Economic History of Italy. Oxford: Clarendon Press, 1993. 